\title{
A REVIEW OF SOVIET DATA ON THE PEACEFUL USES OF NUCLEAR EXPLOSIONS
}

Milo D. Nordyke

April 1, 1974

Prepared for U.S. Atomic Energy Commission under contract No. W-7405-Eng-48

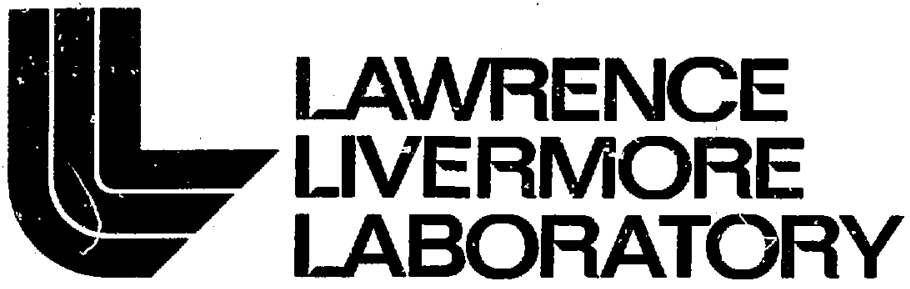

University of California/Livermore

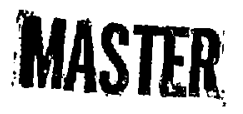




\section{Noticl:}

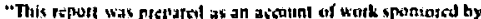

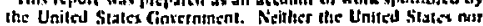

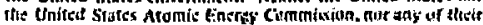

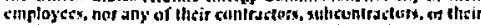

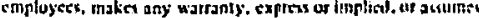

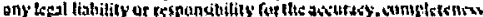

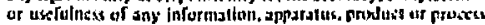

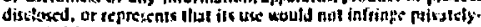
awned sights.

Printed in the United States of Anierica Available from

National Technical Information Service

U.S. Department of Commerce 5285 Port Royal Road

Springfield, Virginia 22151

Price: Prirted Copy $\$$;

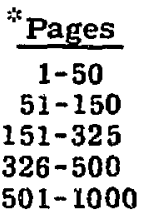

NTIS

Selling Price

$\$ 4.00$

$\$ 5.45$

$\$ 7.60$

$\$ 10.60$

$\$ 13.60$ 
TID-4500, UC-35

Peaceful Appilications and Explosions

\title{
㢟
}

\section{LAWRENCE LNEPMORE LAEORATORY}

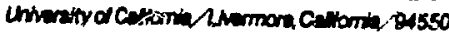

\section{UCRL-51414, Rev. I \\ A REVIEW OF SOVIET DATA ON THE PEACEFUL USES OF NUCLEAR EXPLOSIONS}

\author{
Milo D. Nordyke
}

IMS. date: April 1, 1974

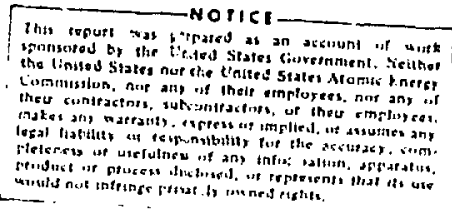

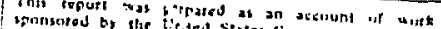

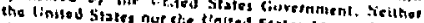

Liomansiles.

Cuter

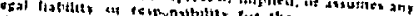

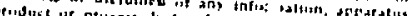

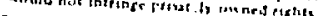




\section{Contents}

Introduction

The Soviet PNE Program

Excavation Experiments and Applications

Water Resource Development

Crater Lip Danss

"1003"

"1004"

Proposed Crater Lip Dam

Canal Construction

$\mathrm{T}-1$

$\mathrm{T}-2$

Proposed Pechora-Kama Canal

Overburden Removal

Contained Experiments and Applications

Sealing of Runaway Wells

Field 1-Lrtabulak

Second Field

Oil Stimulation

Field $A$

Field $B$

Proposed Field $C$

Gas Stimulation

Proposed Nuclear Gas Stimulation Project . • . . . . . 29

l'nderground Stcrage of Gas and Oil . . . . . . . . . . 30

1. 1-kt Explosion in Salt . . . , . . . . . . . 3:

25-kt Explosion iл Salt . . . . . . . . . . . . 33

Industrial Testing of a Nuclear Storage Cavity . . . . . . 33

Proposed Gas Condensate Storage in Salt . . . . . . . 35

Proposed Gas Storage in Welded Tuff . . . . . . . . . 35

Mineral Development . . . . . . . . . . . . . 35

Proposed Ore Breaking Project . . . . . • . . . . 38

Scismic Events in the Soviet Lnion Presumed to be PNE Explosions . . . . 39

Summary

References

Appendix $A-$ The Virtabulak Field 


\section{A REVIEW OF SOVIET DATA ON THE PEACEFUL USES OF NUCLEAR EXPLOSIONS}

\section{Introduction}

Over the last several years through a series of international meetings sponsored by the International Atomic Energy Agency (IAEA) and a number of publications, ${ }^{1-4}$ the Soviet Union has disclosed that they have a very active program for developing peaceful uses of nuclear explosions (PNE) in their national economy. They have described the results of 14 experimental and industrial explosions designed to develop nine different applications in the petrolet:m, gas, and minerals industries as well as for water resources deveiopment. However, when one con- siders the large number of large unidentified seismic events that have been reported over the last seven years in areas of the Soviet Union outside the normal nuclearweapon test areas, it is obvious that they have an even more active program than they have publicly described, one that must be approaching a routine industrial technology in some areas. In this paper. the PNE program that the Soviets have publicly discussed in various reports and at various meetings is summarized and, when appropriate, compared to data from the JS Plowshare Program.

\section{The Soviet PNE Program}

Tables 1 and 2 list 14 nuclear explosions that the Soviets have publicly described as having been carried out as part of their PNE program. Table 1 is for excavation applications and Table 2 is for contained applications. Also shown in Tables 1 and 2 are a number of applications or projects they are planning to carry out in the fut re.

\section{EXCAVATION EXPERIMENTS AND APPLICATIONS}

Water Resource Development

Crater Lip Dams - Two nuclear explosions have been carried out that were directed toward the development of water storage reservoirs through the use of crater lip dams. 
Table 1. Soviet excavation PNE applications.

\begin{tabular}{|c|c|c|}
\hline Application & Explosives & Comments \\
\hline \multicolumn{3}{|l|}{ Water Resource Development: } \\
\hline 1003 & $1.1-k: t$ & Cratering shot in siltstone \\
\hline 1004 & $125-k t$ & $\begin{array}{l}\text { Crater in river producs two lakes, } \\
13,000 \text { acre-ft-"Fruven Technology" }\end{array}$ \\
\hline Proposed Reservoir & Two $150-k t$ & To form 24,000 acre-ft reservoir \\
\hline$T-1$ & $0.2-\mathrm{kt}$ & $\begin{array}{l}\text { Cratering shot in sandstone } \\
\text { calibration for } \mathrm{T}-2\end{array}$ \\
\hline$T-2$ & Three $0.2-\mathrm{kt}$ & $\begin{array}{l}\text { Row charge cratering shot "model } \\
\text { of Pechora-Kama" }\end{array}$ \\
\hline $\begin{array}{l}\text { Proposed Pechora-Kama } \\
\text { Canal }\end{array}$ & 250 explosives & $\begin{array}{l}\text { Divert Pechora River into Kama } \\
\text { River and thence to Caspian Sea }\end{array}$ \\
\hline \multicolumn{3}{|l|}{ Overburden Removal: } \\
\hline Proposed Mining Project & $\begin{array}{l}\sim 1-\text { Mt row } \\
\text { charge }\end{array}$ & $\begin{array}{l}\text { Will remove } 900,000,000 \mathrm{~m}^{3} \text { of } \\
\text { overburden at } 5 \mathrm{k} / \mathrm{m}^{3}\end{array}$ \\
\hline
\end{tabular}

"1003"-This was a 1.1-kt cratering explosion carried out in a siltstone-type rock which was overlaid with a layer of clay about 20 meters thick and a surface layer of loam 3.7 meters thick. The explosive was emplaced at a depth of 48 meters. An artesian water table existed at a depth of about 14-20 meters. The crater initially had an apparent depth of 31 meters and an apparent radius of 53.5 meters. As a result of sluffing under the action of the artesian water flowing into the crater, the apparent crater depth had decreased to 20 meters anc' the apparent ratius had increased to 62 meters within two years. Figure 1 presents a topographic plan and Fig. 2 a cross section of "1003" as it existed two years after the detonation. Or particular interest is a low point or trench through the lip in the southwestern quadrant which was created by burying a row of high explosive (HE) charges along a radial line before the nuclear shot. Two hours after the nuclear shot, these HE row charges were detonated, excavating the trench through the lip, which could tave served as an "inlet canal" had the crater been made near a river bed.

"1004"-This was a nuclear cratering event with a yield of "over 100-kt." The depth of burst is quoted as being "about 200 meters." The medium is characterised as being interbedded layers of sandstone, siltstone, shale, and conglomerates of the Del'begetay suite, with a moisture content of $12 \%$. Immediately after the shot, the "1004" crater hid an apparent crater radius of 204 meters and an apparent crater depth of 100 meters. These dimensions compare fairly well with the 100-kt Sedan crater (194-meter depth of burst, 185-meter apparent radius, and 98-meter apparent depth). 
Table 2. Soviet contatned PNE applications.

\begin{tabular}{|c|c|c|}
\hline Appication & Expiosives & Comments \\
\hline \multicolumn{3}{|l|}{ Contrul of Runaway Well.s: } \\
\hline Urte ulak & $30-k t$ & $75 \mathrm{M}$ lost over 3 years \\
\hline Nearby Gas Field & $40-k t$ & "Prove.2 Technology" \\
\hline \multicolumn{3}{|l|}{ Oil Stimulation: } \\
\hline Fjeld A & $\begin{array}{l}\text { Two } 2.3-k t+ \\
\text { one } 8-k t\end{array}$ & $\mathbf{2 6 \%}$ internal rate of return in US \\
\hline Field $B$ & Two 8-kt & "Proven Technulogy" \\
\hline Proposed Field $r$ & Three $20-30 \mathrm{kt}$ & $\begin{array}{l}\text { Designed to break barrier so under- } \\
\text { lying water will push oil out }\end{array}$ \\
\hline \multicolumn{3}{|l|}{ Gas Stimulation: } \\
\hline Undescribed & - & $\begin{array}{l}\text { Statement that such an appiication } \\
\text { was carried out }\end{array}$ \\
\hline $\begin{array}{l}\text { Proposed Gas Condensate } \\
\text { Field }\end{array}$ & Three 40-kt & $\begin{array}{l}\text { Expect increase from } 7.5 \mathrm{MMCF} / \mathrm{D} \\
\text { to } 100 \mathrm{MMCF} / \mathrm{D}\end{array}$ \\
\hline \multicolumn{3}{|c|}{ Underground Storage of Oil or Gas: } \\
\hline Salt Dome $A$ & $1.1-\mathrm{kt}$ & $\begin{array}{l}\text { Salt dome-leaked water and radio- } \\
\text { activity }\end{array}$ \\
\hline Salt Dome B & $25-\mathrm{k} \hat{\imath}$ & $\begin{array}{l}10^{6} \text { bbl storage at } 1 / 6 \text { surface gas } \\
\text { storage and } 1 / 3 \text { washed cavities } \\
\text { cost }\end{array}$ \\
\hline Unidentified Cavity & - & Tested with oil and gas at 60 atm. \\
\hline Proposed-Layered Salt & Two 35-kt & $\begin{array}{l}\text { Require } 2 \times 10^{6} \mathrm{bbl} \text { storage for } \\
\text { gas condensate }\end{array}$ \\
\hline $\begin{array}{l}\text { Proposed-Tuff Under } \\
\text { Permafrost }\end{array}$ & Three 40-kt & $\begin{array}{l}\text { Require } 2.5 \mathrm{BCF} \text { storage for gas } \\
\text { at } 70 \text { atn. }\end{array}$ \\
\hline \multicolumn{3}{|l|}{ Mineral Development: } \\
\hline "Granddaddy Shot" & $1-\mathrm{kt}$ & Granite shot similar to Hardhat \\
\hline Proposed Ore Breaking & $1.8-\mathrm{kt}$ & Will break $\sim 10^{6} \mathrm{~m}^{3}$ of ore in-situ \\
\hline
\end{tabular}

The "1004" event was placed immediately adjacent to a river bed in order that the lip of the crater would block the river and a large water reservoir would be former. Figure 3 is a winter view of the general area of "1004", showing the rive: on the left and the outcropping Del'begetay suite of rock on the right. Based on the animation sequence in the
Soviet movit 5 about "1004" from which Fig. 3 was triken, the ground zero location was probably close to the dark spot on the left bank of the river just to the left of the center of the picture. Fig. 4 is a composite photograph showing the crater filled with $7 \times 10^{6}$ L. $^{3}$ (5675 acre$\mathrm{ft}$ ) of water and a reservuir backed up behind the lip of the crater containing 


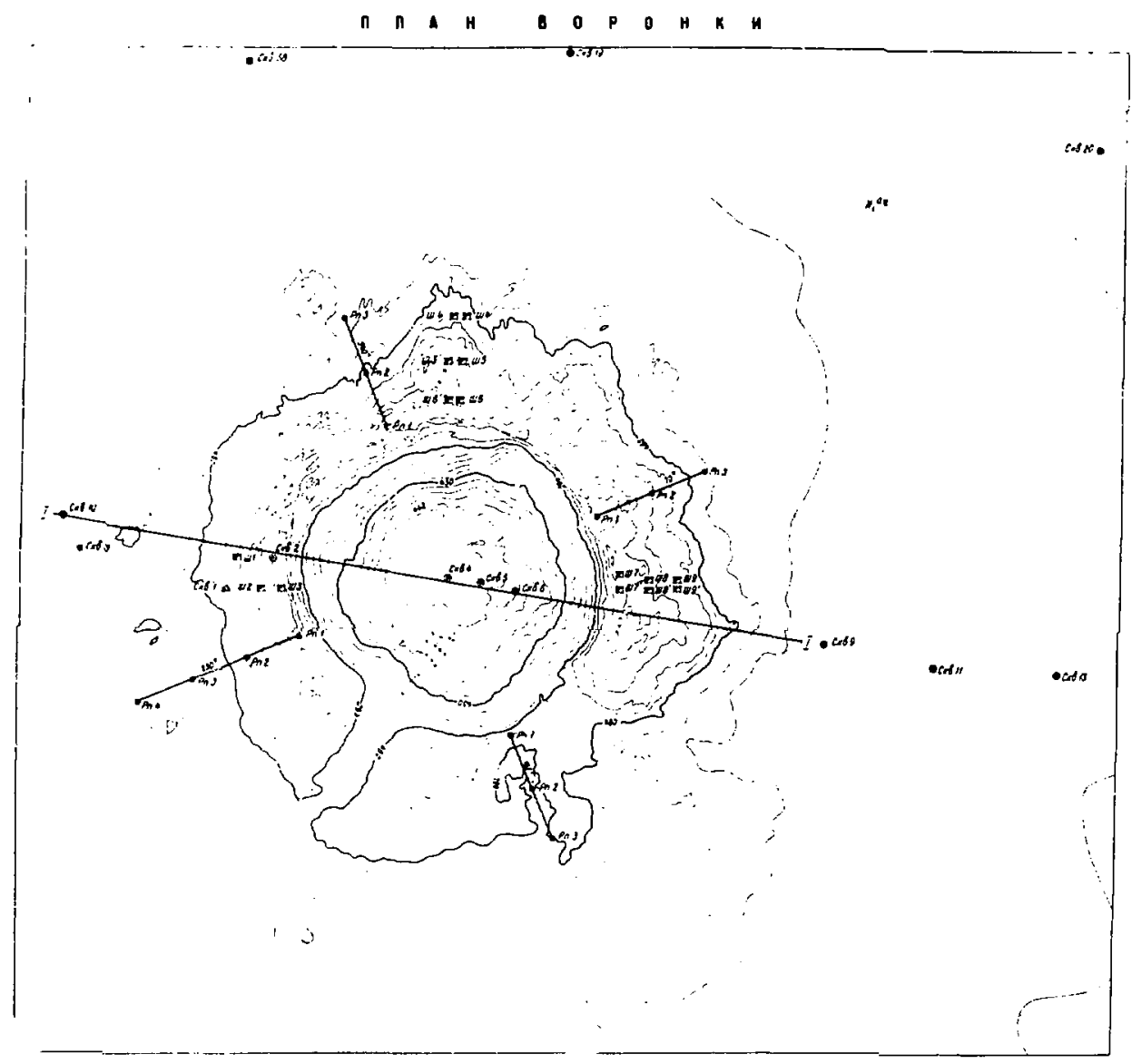

Fig. 1. Topographic plan view of "1003" project crater two years after detonation.

$10^{7} \mathrm{~m}^{3}$ (8100 acre-ft). Or special note is the channel that was dug through the lip to flood the crater and interconnect the two reservoirs. Figure 5 shows this channel in detail with the two men in a bcat giving scale.

Filling of the crater with water resulted in sibstantial readjustment of some of the slopes of the crater. Figure 6 shows one of the side slopes where the results of this readjustment are quite apparent in the small escarpment. The changes in the side slopes during the three to five years following filling are as follows:

North South East West

Initial $30^{\circ} \quad 55^{\circ} \quad 40^{\circ} \frac{35^{\circ}}{30^{\circ}}$

Final (+ $3-5$ years) $30^{\circ} \quad 40^{\circ} 30^{\circ} \quad 20^{\circ}$

Some $1,700,000 \mathrm{~m}^{3}$ of rock slid into the crater, mostly from the south side, 


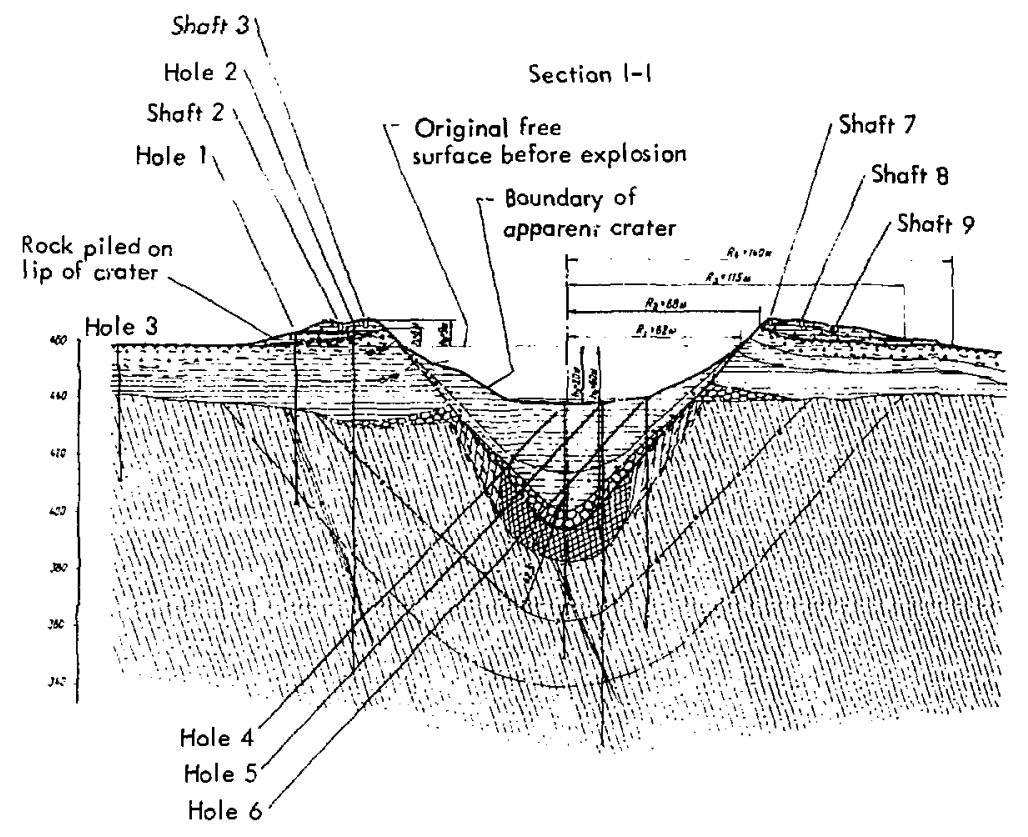

\section{Legend}

- Holes bored, preshot

- Holes bored, postshot

- Shofrs

- Datum masks ro study subsidence Boundary of fallback of ejected rock

$n^{32}$ Clay

[TI Soil and plant layer with loam

Srey-green and brown cloy

Eiv siltstone

$\therefore$ Diabasic porphyrites

Clay with chips of siltstone (more than 30\%)

Fractured siltstone

Crushed zone

- -- Lower limit of zone of intense fracturing

-.-. Lower limit of zone of block fracturing

$E=0$ Grey-green cloy

$E$ Brown cloy

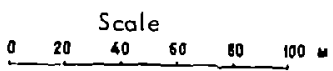

Fig. 2. Cross section of "1003" project two years after detonation. 


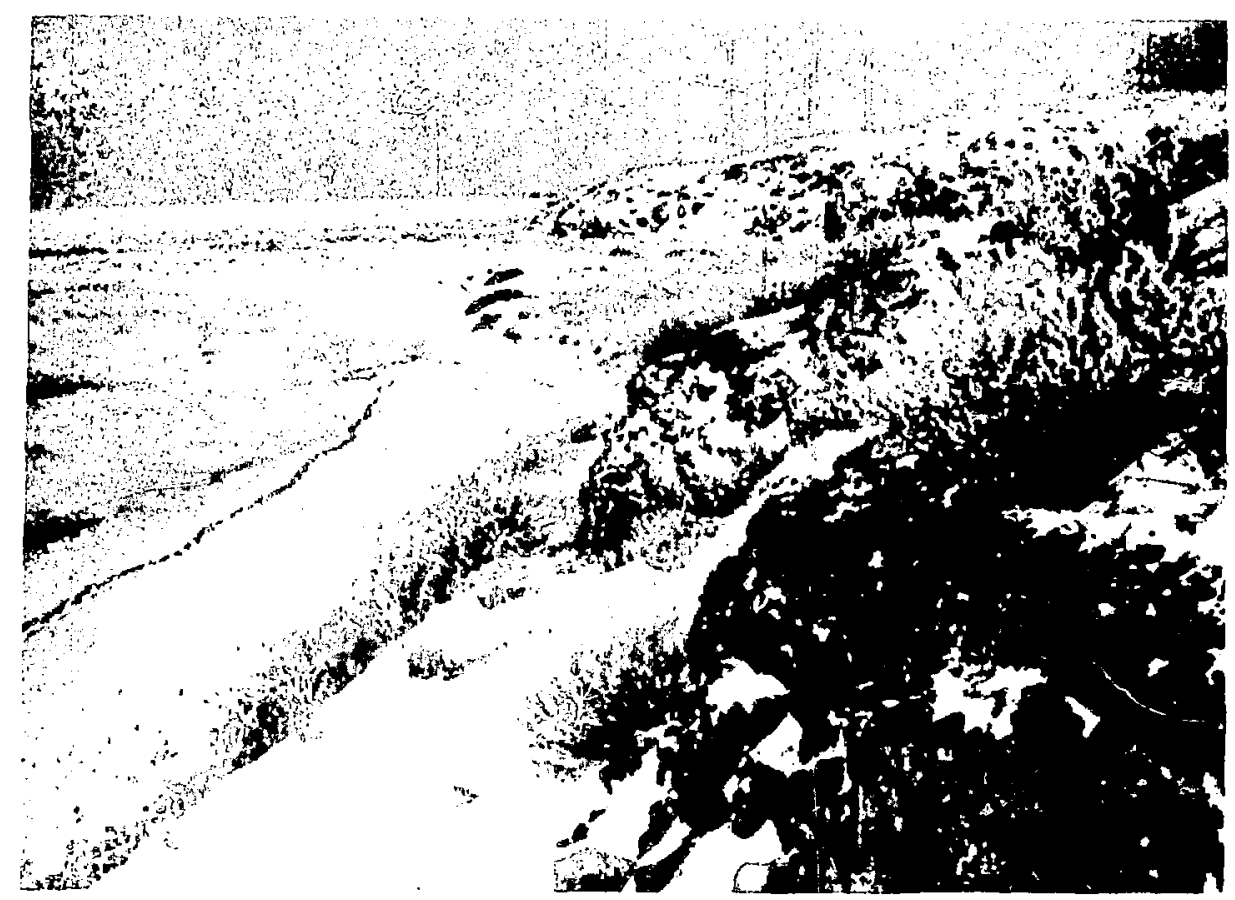

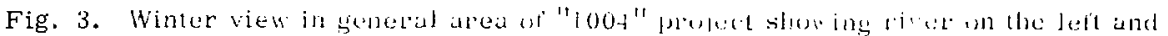

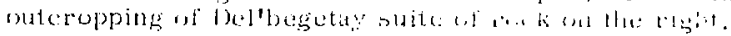

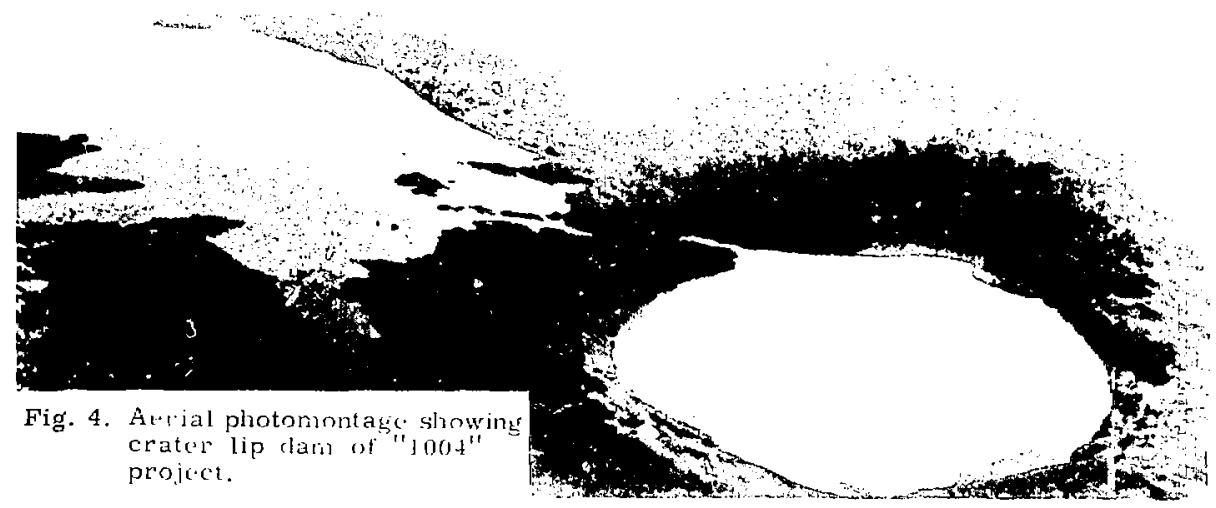




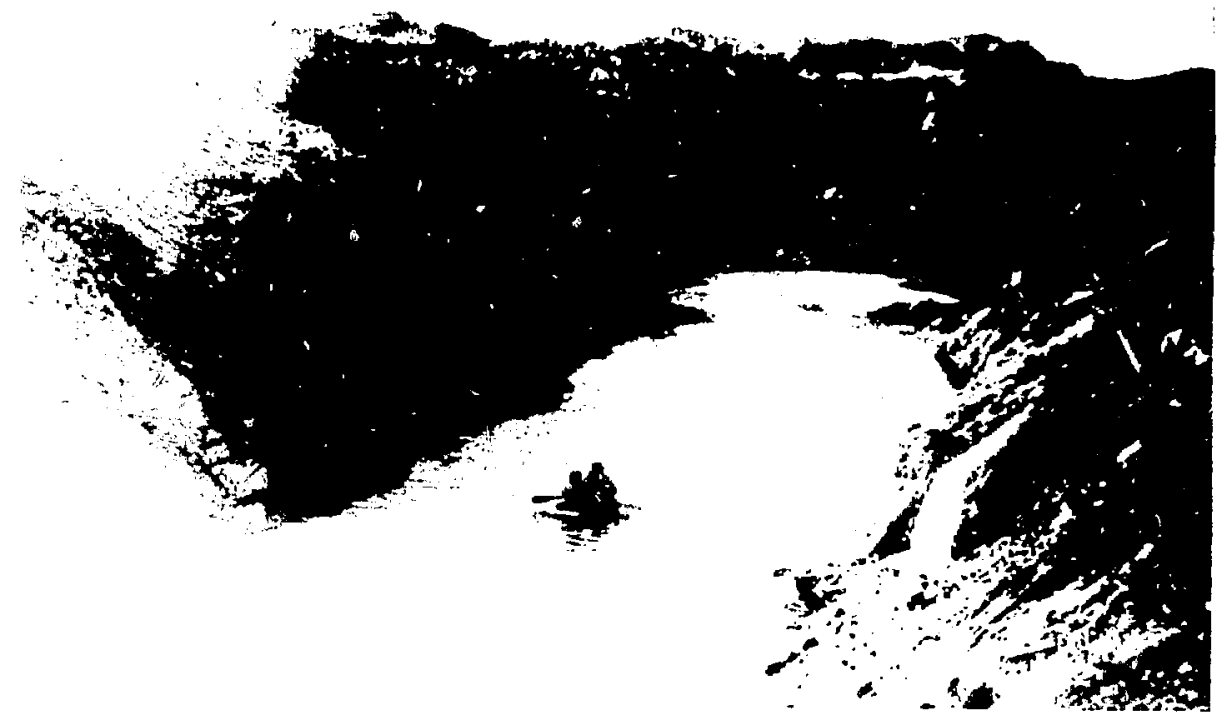

Fig. 5. Cirmulad sew of interconnesting channel throigh crater lip dam.

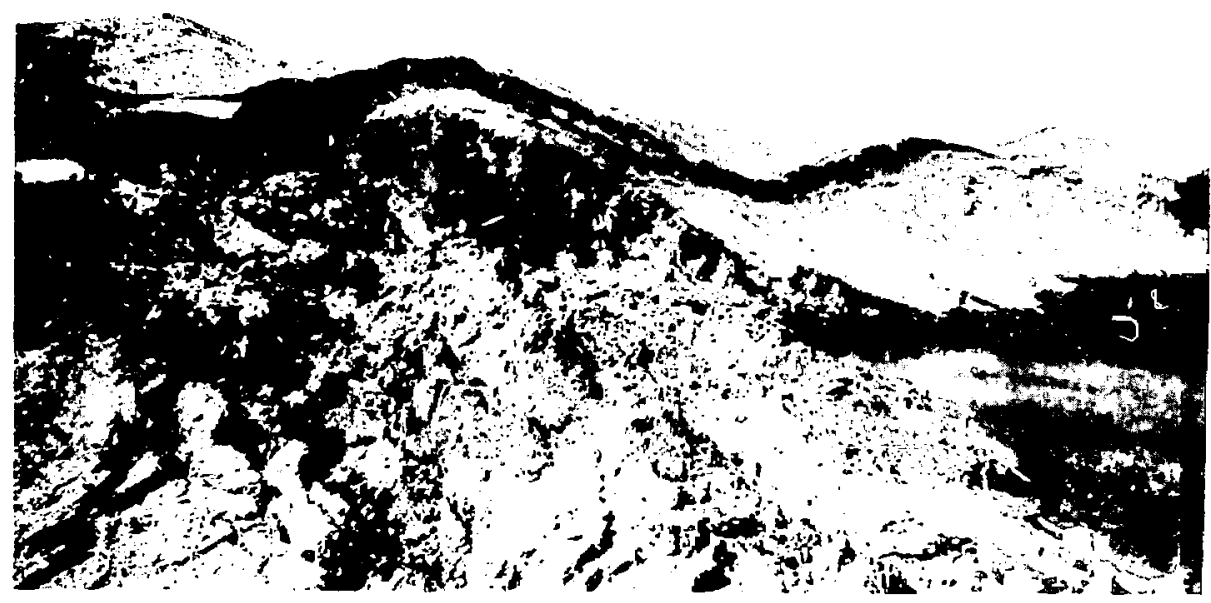

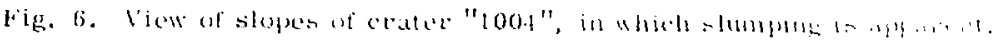


reducing the apparent crater depth by

17 meters to 83 meters and the apparen crater volume by $22 \%$ from $6.4 \times 10^{6}$ to $5.7 \times 10^{6} \mathrm{~m}^{3}$. The crater is reported to have stabilized in thia configuration ${ }^{6}$ and continues to stand as a useful crater reservoir at last report.

Figure 7 is a cross section of the "1004" crater showing the complicated geological structure and the various zones around the crater as defined by the extensive postshot exploratory drilling and shafts. This figure indicates that the depth of burial was about 174 meters. Izrael in Ref. 7 states the scaled depth of burial as $4 \mathrm{~m} / \mathrm{ht}^{1 / 3 . t}$ which would indizate a yield of about $1-j 7-k t$. In l*ig. 5 of Ref. B Myasnikov indicates the scaled apparent raclius is $51 \mathrm{~m} / \mathrm{k}^{1 / 3 . t}$ which, for an apparent crater radius of 204 meters, would give a yield of 111 -kt. Myatsnikor also uses a scaled depth of burst for 1004 of $50 \mathrm{~m} / \mathrm{kt}^{1 / 3.4}$ in fig. 5 of Ret. 35. lior at deptr of burst of 170 meters, this corresponds to a yield of 75 -kt which is very much too low. A scaled depth of burial of $50 \mathrm{~m} / \mathrm{kt}^{1 / 3.4}$ does, in fact, correspond to $111-k 1$ at 200 meters which is the approximate emplacenrent depth given in Refs. 3, 7, and \%. Averaging these three possible yields we have a value of about $125 \pm 15 \mathrm{kt}$ for "1004".

Pigure $\theta$ is modified from ligh. 5 of Ref. 8 to include the US curres for scaled radius vs scaled depth of burst for NIS desert alluvium and hard dry rock irom Toman," Curve 1 is described by Myasnikov as representing explosirizs in rocks "containing a significaut amount of easily vaporized constituents" such as water, while Curve 2 is tor rocks "latcking, in casily vaporized components, containing less than 10: water." The lis and

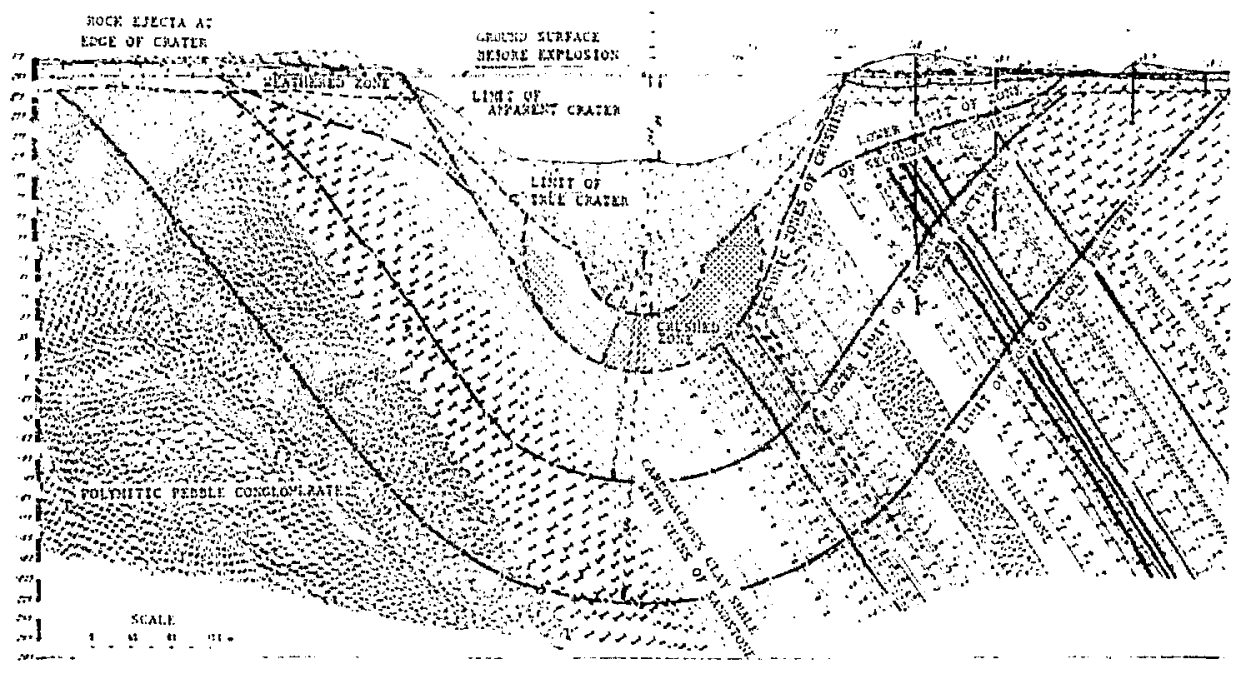

Fig. 7. Cieologic cross section through "1004" arter explosion. 


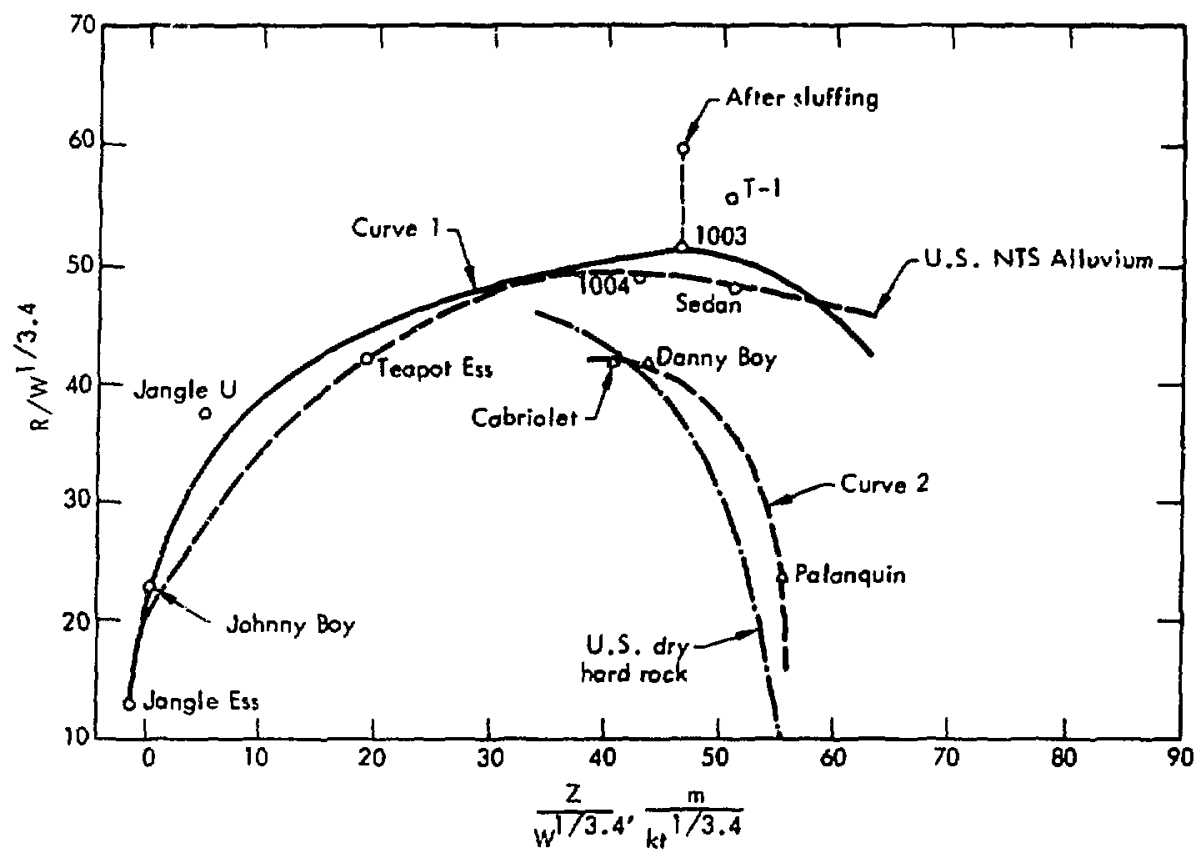

Fig. 8. Scaled apparent crater radius, vs scaled depth of burst for Soviet and US shots.

Soviet curves appear to be very similar. Also shown in Fig. 8 are the data points for "1003" and "1004" and the 0.2-kt crater T-1 which will be discussed later. The data point for "1004" has been replotted using depth of burst of 178 meters, a radius of 204 meters, and a yield of $125-\mathrm{kt}$. Thus, the radii of "1003" and "1004" af sear to be quite consistent with previou: US and Soviet data for weak rocks that have a significant quantity of vapor-forming constituents (e.g., 6-10\% $\mathrm{H}_{2} \mathrm{O}$ ).

Figure 9 is a similar plot showing scaled depth ys depth of burst. We do not have the Soviel curves for comparison and only the US curves are shown. The initial depth of "1004" falls a little below the US alluvium curve, whereas the initial depth of "1003" is considerably above the alluvium curve. Similar scatter in crater de, ths on such a plot is not unusual.

\section{Proposed Crater Lip Disn-Fig-} ure 10 shows a proposed crater lip dam described by the Soviets involving the detonation of two $150-\mathrm{kt}$ explosives at a depth of 185 meters $\left(42.4 \mathrm{~m} / \mathrm{kt}^{1 / 3.4}\right)$ in a porphyrite medium. The expected radii and depths of the two craters are 180 meters and 105 meters, respectively. Thsse correspond to scaled dimensions of $41 \mathrm{~m} / \mathrm{kt}^{1 / 3.4}$ and $24 \mathrm{~m} / \mathrm{kt}^{1 / 3.4}$. Comparison of these scaled dimensions with Figs. 8 and 9 show that the scaled radius 


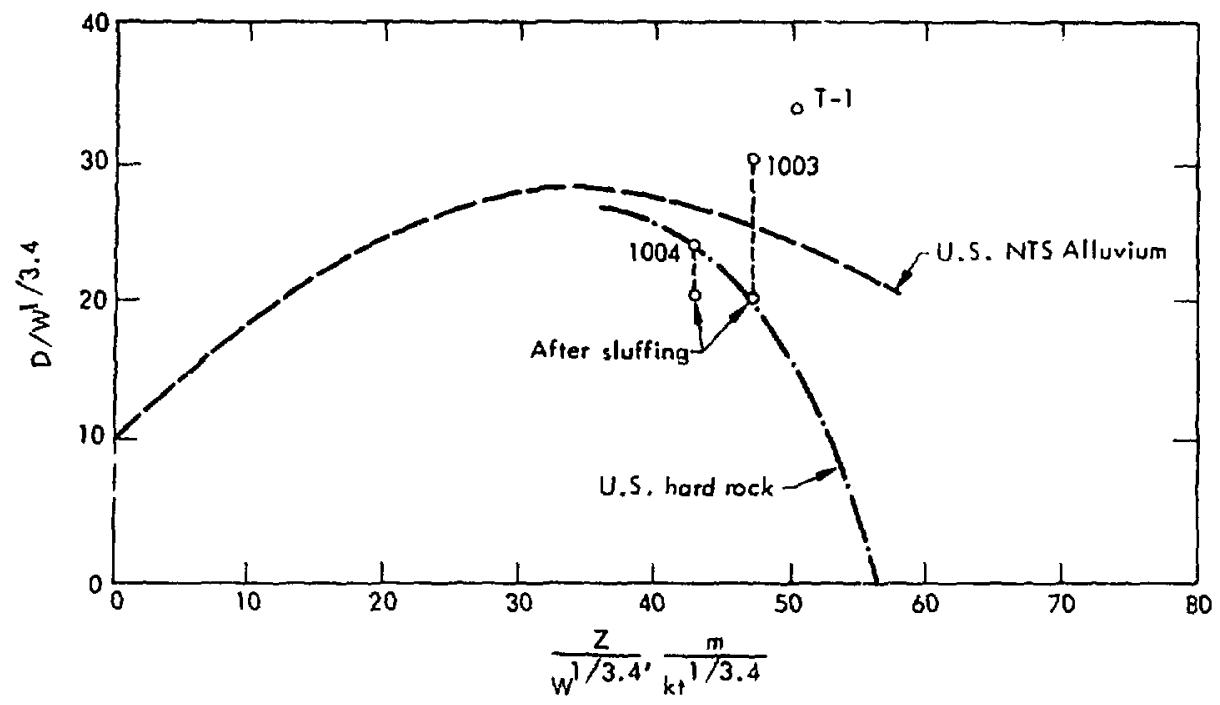

Fig. 9. Scaled apparent crater depth vs scaled depth of burst, US curves are shown for comparison.

is significantly smaller than " 1004 ". indicating that ihis material is expected to be similar to the hard, dry rock curve and the US craters Cabriolet and Danny Boy. The scaled depths are in good agreement with those of "1004" which fall approximately on the US hard rock curve.

The crater lips that are expected to form the twin dams are predicted to be 31.5 meters high. Howiver, it is indicated that the lake behind the lip dams is only expected to be 10 meters cieep with a maximum capacity of $30 \times 10^{6} \mathrm{~m}^{3}$ $(24,000$ acre-ft $)$. An additional $14 \times 10^{6} \mathrm{~m}^{3}$ (11,000 acre-ft) of storage would be available inside the craters.

\section{Canal Construction-Over the last} 30 years the Soviets have developed a large body of experience and have constructed many major canals with rows of cratering explosions. For example, in 1963-6t they used over 25-kt of chemical cxplasives to excavate a $37-\mathrm{km}$ secto: of the Amu-liukhara Camal. Thereforf, when they developed plins for the construction of a major canal to clivert the waters of the P'echor a River w llow into the Volga-Kama bystem, explosive excavation was considered one of the primary tools. To provide experimental data on which to base their plans for future canal construction, a series of chemical explosive row charges involving five or six charges with charge weights of 600-650 kg were fired. In addition, two nuclear cratering experiments were carried out.

$\mathrm{T}-1$-The $\mathrm{T}-\mathrm{I}$ event was a single $0.2-k t$ nuclear cratering explesion carried out in a quartione sandstone 


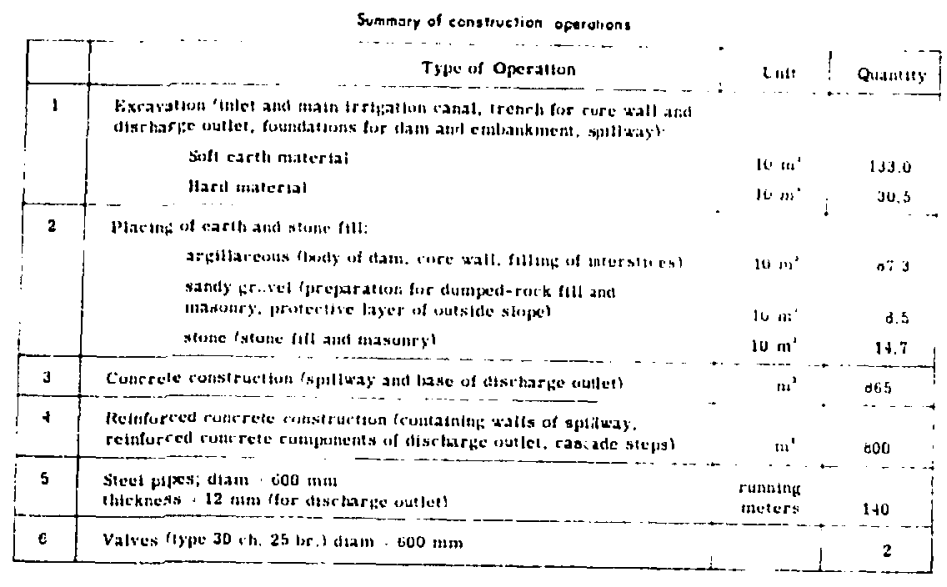

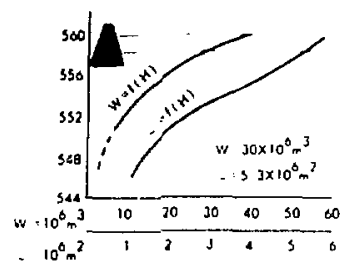

Gutves of the reservolp walume and area
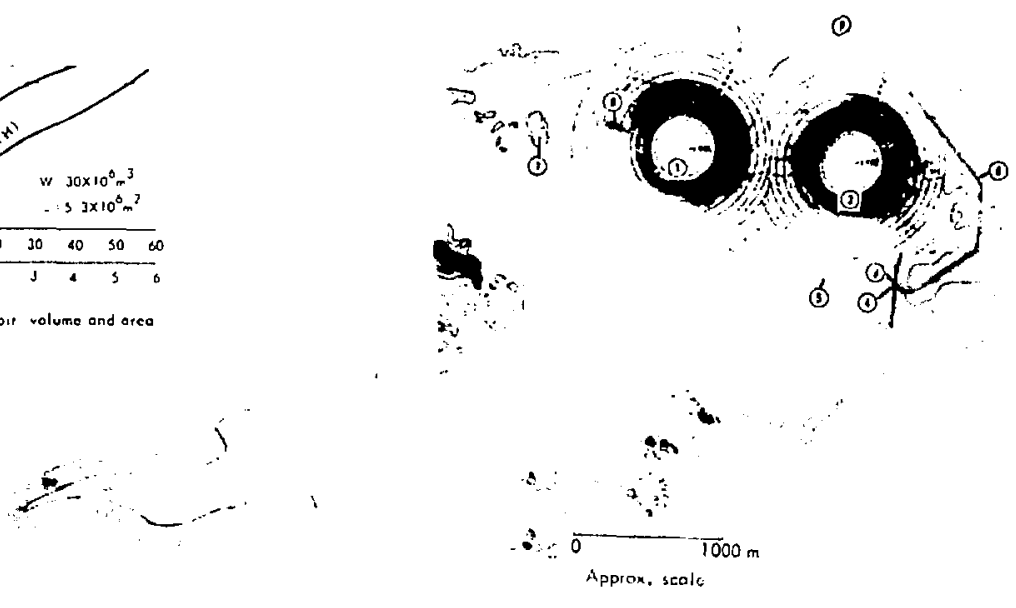

Crater lip paraneters

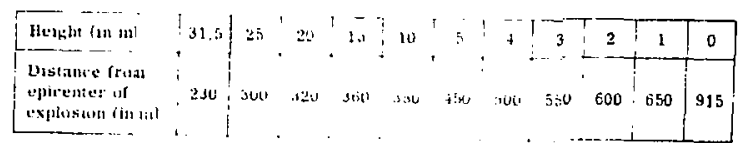

Fig. 10. Pan for proposed crater lip dan. Numbers un ligure inclicate the principal components of the projecl (1) earth-fill dam 1; (2) earth-fill darl 2; (3) earthfill dam $3 ;(4)$ discharge output; (5) inlet canal; (6) main irrigation canal; (7) spillway; (8) embankment; (9) existing irrigatlin (andl. 
interstratified with argillite and siltstone containing considerable organic residue. The gasforming material in the rock was about $12.8 \%$, although the moisture content was only about $5.2 \%$. The water table was at a depth of about 2 meter's. The depth of burst was 31.4 meters (50.4 $\left.\mathrm{m} \cdot \mathrm{kt}^{1 / 3.4}\right)$.

Figure 11 is a topographic contour map of the cr ter. Myasrikov gives the

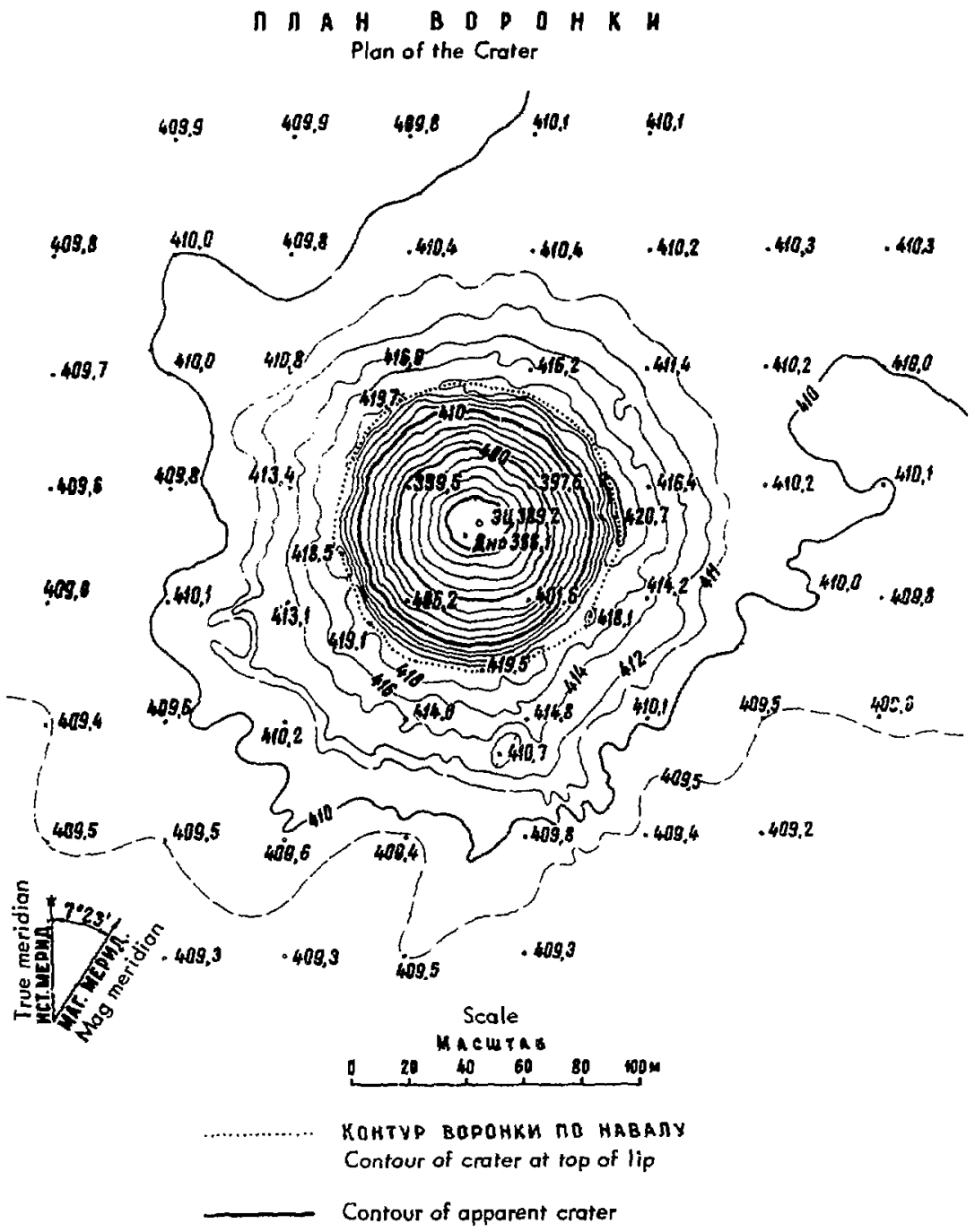

Fig. 11. Topographic contour map of T-1 crater. 
apparent crater radius as 34-40 meters $\left(55-64 \mathrm{~m} / \mathrm{kt}^{1 / 3.4}\right)$ and uses a value of 35 meters ( $56 \mathrm{~m} / /^{1} \mathrm{t}^{1 / 3.4}$ ) for plotting in our Fig. 8. This latter value is somewhat above "1003" and the curve for weak, gas-forming materials. However, from Fig. 11 the average radius would appear to actually be more like 40 meters $\left(64 \mathrm{~m} / \mathrm{kt}^{1 / 3.4}\right)$ which would put the radius data point far above the curves in Fig. 8. The depth of the apparent crater is given as 21 meters $\left(34 \mathrm{~m} / \mathrm{kt}^{1 / 3.4}\right)$ which is also significantly above all the other corresponding data in Fig. 9. Myasnikov states that the crater turned out to be $40 \%$ deeper and $25 \%$ wider than they had expected. Because of the shallow water table, the crater filled with water within several days.

\section{T-2-The T-2 event was a row-} charge cratering shot involving three $0.2-k t$ nuclear explosives spaced 40 meters apart. The geology was similar to $T-1$ except that the water table was at a depth of about 5.6-6.9 meters. The depth of burst for the three shots was 31.4 meters, the same as for T-1, giving a ratio of spacing/depth of burst (S/Z) of 1.3. Based on the results of $T-1$ this would correspond to a ratio of spacing/ crater radius $(S / R)$ of $1-1,14$ depending on whether one uses a radius for $T-1$ of 35 or 40 meters. According to both the criteria jescribed by Myasnikov using $S / Z$ or the US criteria based on $S / R$, this spacing would be expected to lead to about $10 \%$ enhancement of crater radius and no enhancement of crater depth.

Figure 12 is a topographic contour map of the T-2 crater. The width of the row crater ranged between 61 and 69 meters, averaging about 65 meters. The depth was about 16 meters. Thus, the crater was $20-30 \%$ narrower and about $25 \%$ shallower than expected on the basis of the T-1 crater. When judged relative to "1003", hovever, the T-2 crater has about the expected dimengions.

\section{Proposed Pechora-Kama Canal-As}

a result of climatic anomalies and olternate beneftcial uses of the water in the VolgaKama River System, the Caspian Sea has dropped over 2.5 meters in the last 35 years. In order to halt this drop in the level of the Caspian by $6-7 \mathrm{~cm} / \mathrm{yr}$ as well as to meet the increasing demands for water in the European portion of the country, an additional source of water must be found (see Fig. 13). The prime candidates for this source are the northward-flowing rivers that presently flow to the Barents and Kara Seas. Specifically, the Soviets have proposed to divert the flow of the upper portion of the Pechora River into the Kama River and thence to the Volga River through a $112-\mathrm{km}$ canal and a series of four dams and reservoirs. The location of this canal is shown in Fig. 13, and a map showing the canal and reservoirs in more detail is given in Fig. 14.

The northern $65 \mathrm{~km}$ of the canal is planned for construction by nuclear excavation. The geology of this section is generally composed of sandstone, siltstone, anhydrites, and gypsum. The desired canal cross section is $5000 \mathrm{~m}^{2}$. It is envisaged that about 250 explosives, emplaced at depths ranging from 150 to 285 meters will be required. If a scaled depths of burst of $43 \mathrm{~m} / \mathrm{kt}^{1 / 3.4}$ like "1004" are used, these depths of burial imply 


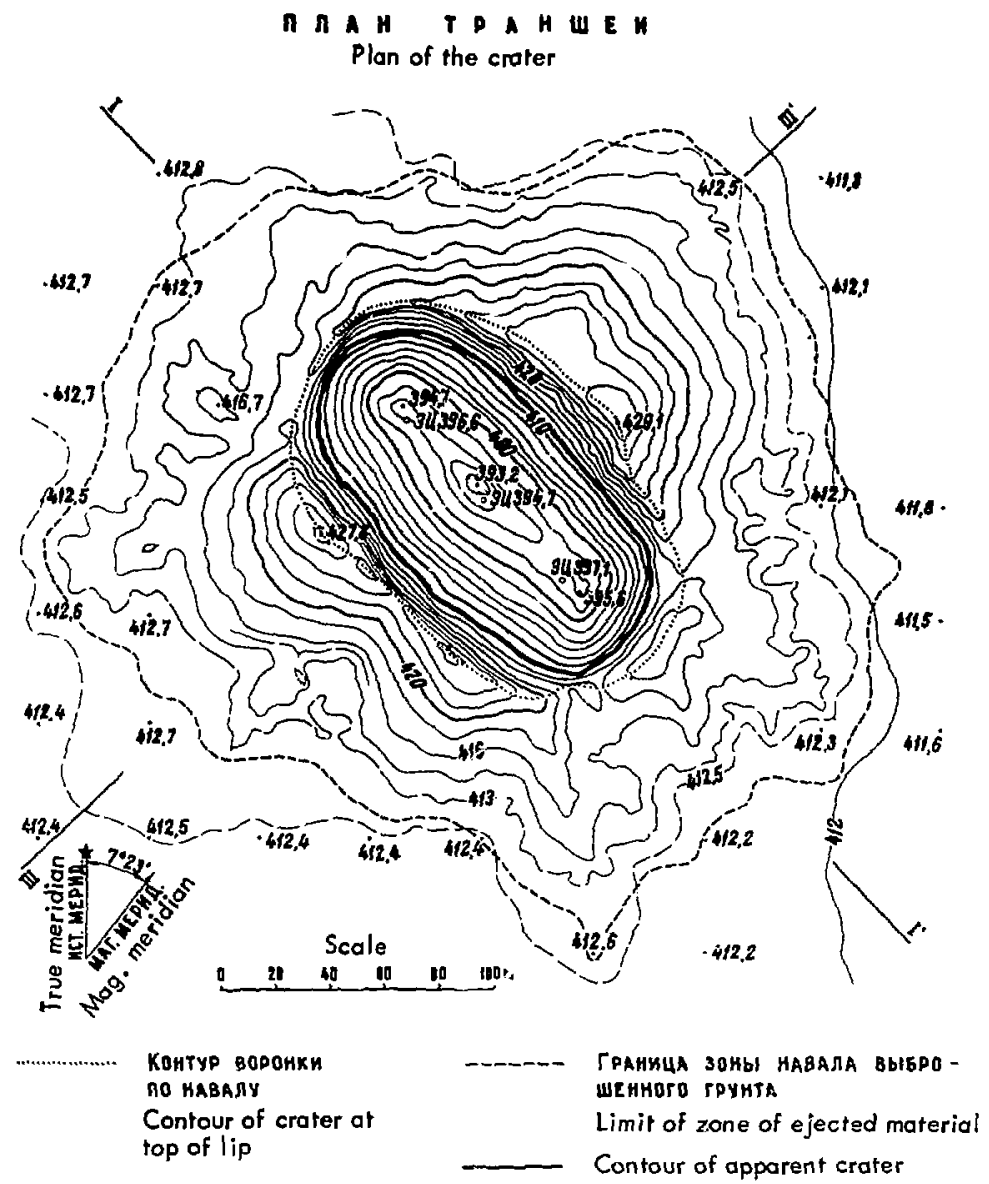

Fig. 12. Topographic contour map of the T-2 crater.

$y$ ields of $70-600 \mathrm{kt}$. If scaled depths of burst of $50 \mathrm{~m} / \mathrm{kt}^{1 / 3.4}$ like $\mathrm{T}-1$ and $\mathrm{T}-2$ are used, yields would be in the range of 40-400 kt. The maximum yield for any one salvo of charges will be $3 \mathrm{Mt}$, the maximum number of charges in a salvo will be 20. The Soviets have estimated that the cost of this canal, if constructed with nuclear excavation, will be 3 to
3.5 times cheaper than by conventional earthmoving methods.

Overburden Removal-The Suviets have described a very large overburden removal project for the mining of a large nonferrous metal deposit which they are considering for nuclear excavation. The climate and economic geography of the 


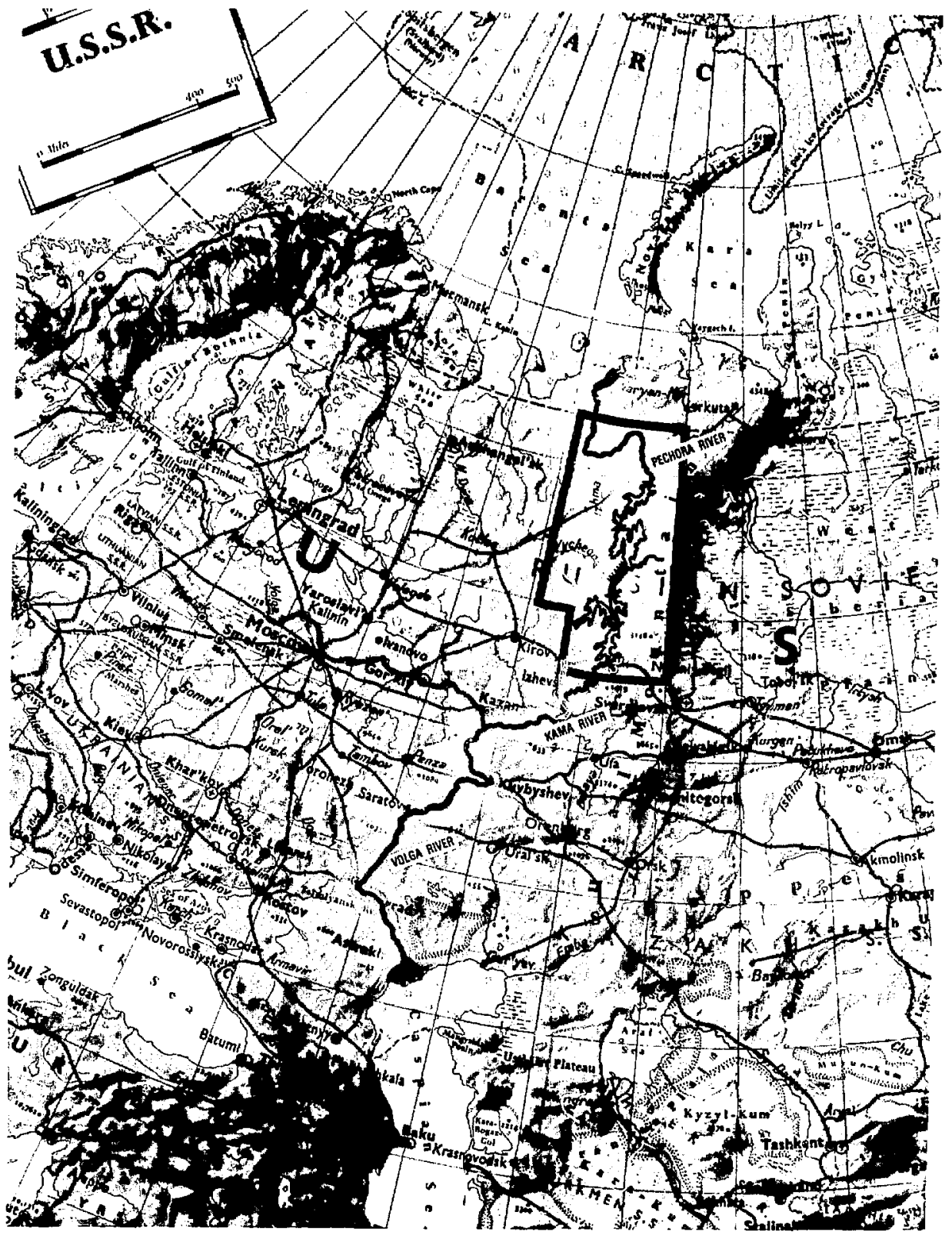

Fig. 13. Location map showing the relation of the Pechora and Kama Rivers to the Volga River and the Caspian Sea. 


\section{CXEMA REPEGPOCK CTOKA ПEИDPG B BOITY}

Daris

Projected hydroelectric stations

- Existing Kamski hydrostatic station

Canal completed by special means

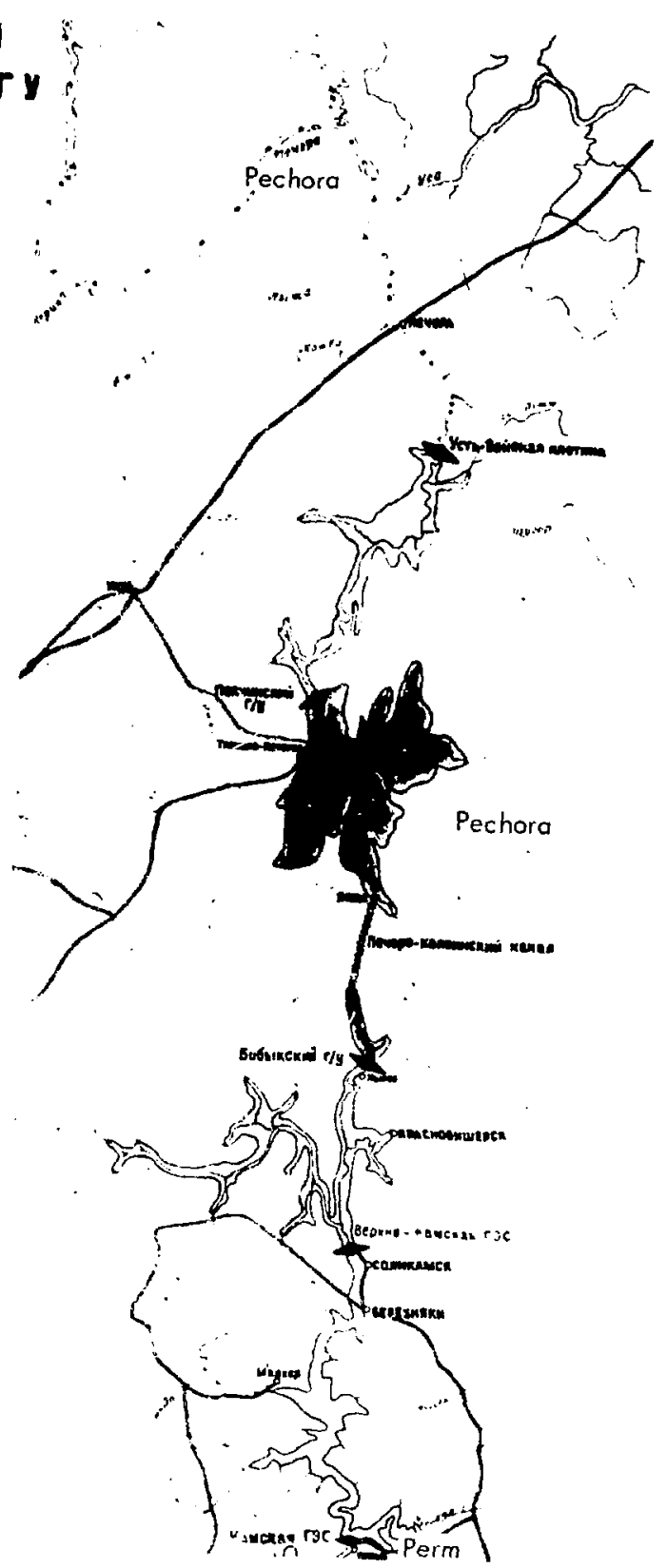

Fig. 14. Hydrological schemes for transferring flow of the Pechora River to the Kama- 
area are described as being similar to the far north but with a high seismicity and frequent earthquakes. Figure 15 is an illustration of this major project showing a comparison between conventional and nuclear excavation. The host rock is described as heing siltstone, argillite, and calcareo:is sandstone. A total of $2,300,000,000 \mathrm{~m}^{3}$ of overburcen must be removed to uncover the area, of which the Soviets feel $900,000,000 \mathrm{~m}^{3}$ can be removed by nuclear excavation at a cost of about 5 kopecks ( 0.05 rubles) per $\mathrm{m}^{3}$ for a savings of over one billion rubles. (By way of comparison, the Kennecott mine near Bingham, Utah, involved the excavation of $1,000,000,000 \mathrm{~m}^{3}$ of overburden over the last 65 years.) Considering the depths involved in the Soviet project, it seems clear that rows of megaton sized explosives will be required.

\section{CONTAINED EXPERIMENTS AND APPLICATIONS ('Table 2)}

\section{Sealing of Runaway Wells}

The sealing of two runaway gas wells in the Soviet Union has been carried out with the aid of nuclear explosions. Although the two gas wells were in deposits that were in close proximity and involved similar geologic structures, the methods of failure and the problems of efiecting a seal were quite different.

Field 1 - Urtabulak-On 1 December 1963, while drilling gas Well No. 11 in the Urtabulak gas field in Southern Uzbekistan, control of the well was lost

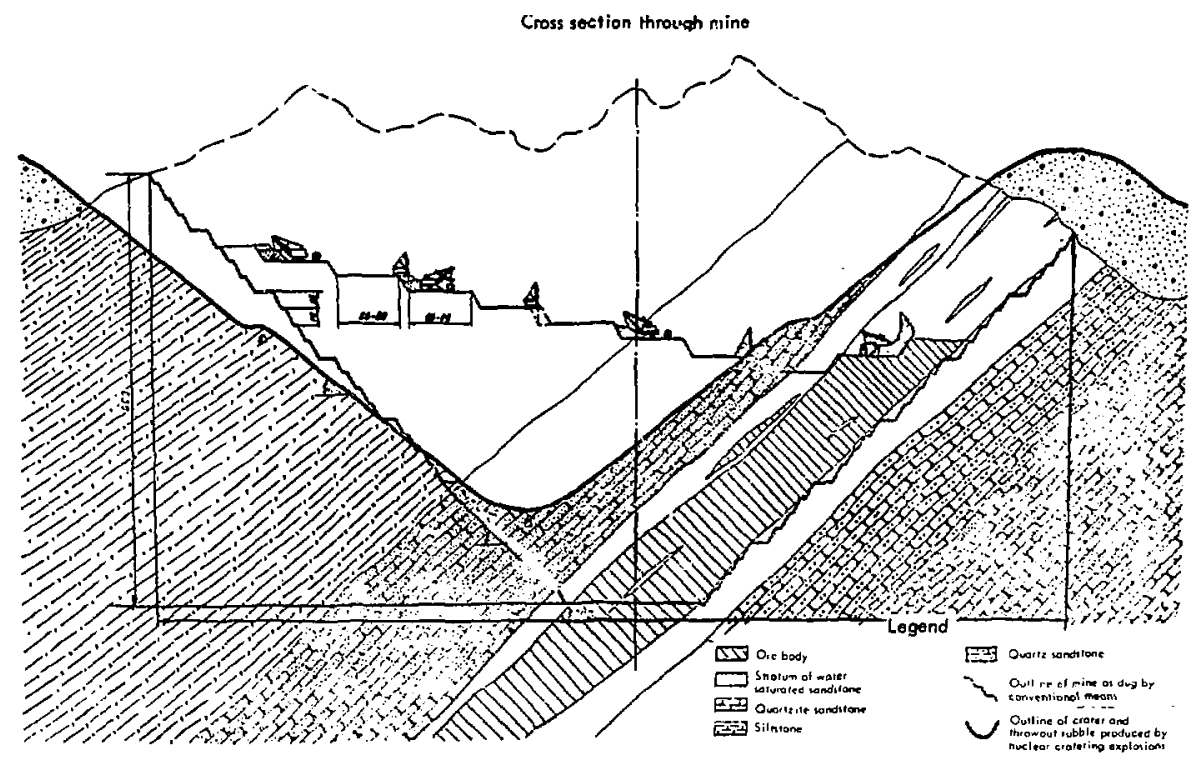

Fig. 15. Comparison of stripping operations conducted in the conventional manner with those using nuclear cratering explosions to remove overburden. 
at a depth of 2450 meters, resulting in uncuntrolled release of over $12 \times 10^{6} \mathrm{~m}^{3}$ (420 MMCF) per day through the 8 -inch casing. ${ }^{7}$ Figure 16 shows the location of the Urtabulak gas-condensate field together with several other gas and gascondensate fields in the central, northern, and eastern portion of Turkmenisten and Western Uzbekisten. Figure 17 is a cross section of the Urtabulak field in the area of Hole No. 11 showing the producing formation, a fissured carbonate rock at "borizon XV." Formation pressures in this area are about 270-300 atmospheres. $10,1 \mathrm{~L}$ (The appendix contains a more detailed description of the Urtabulak Gas Deposit.) Figure 18 is a structural map of the Urtabulak field along the top of the XVth horizon ${ }^{11}$ showing the location of Hole 11 , the runaway well, as well as Holes 1, 2, and 10. At the time of the blowout, Hole 11 had been cased with 8-inch casing to the top of the Kimmeridge-Tithonian salt layer, at a depth of about 2000 meters. However, only the portion from the salt to tho Aptian Clays at 1500 meters had been cemented.

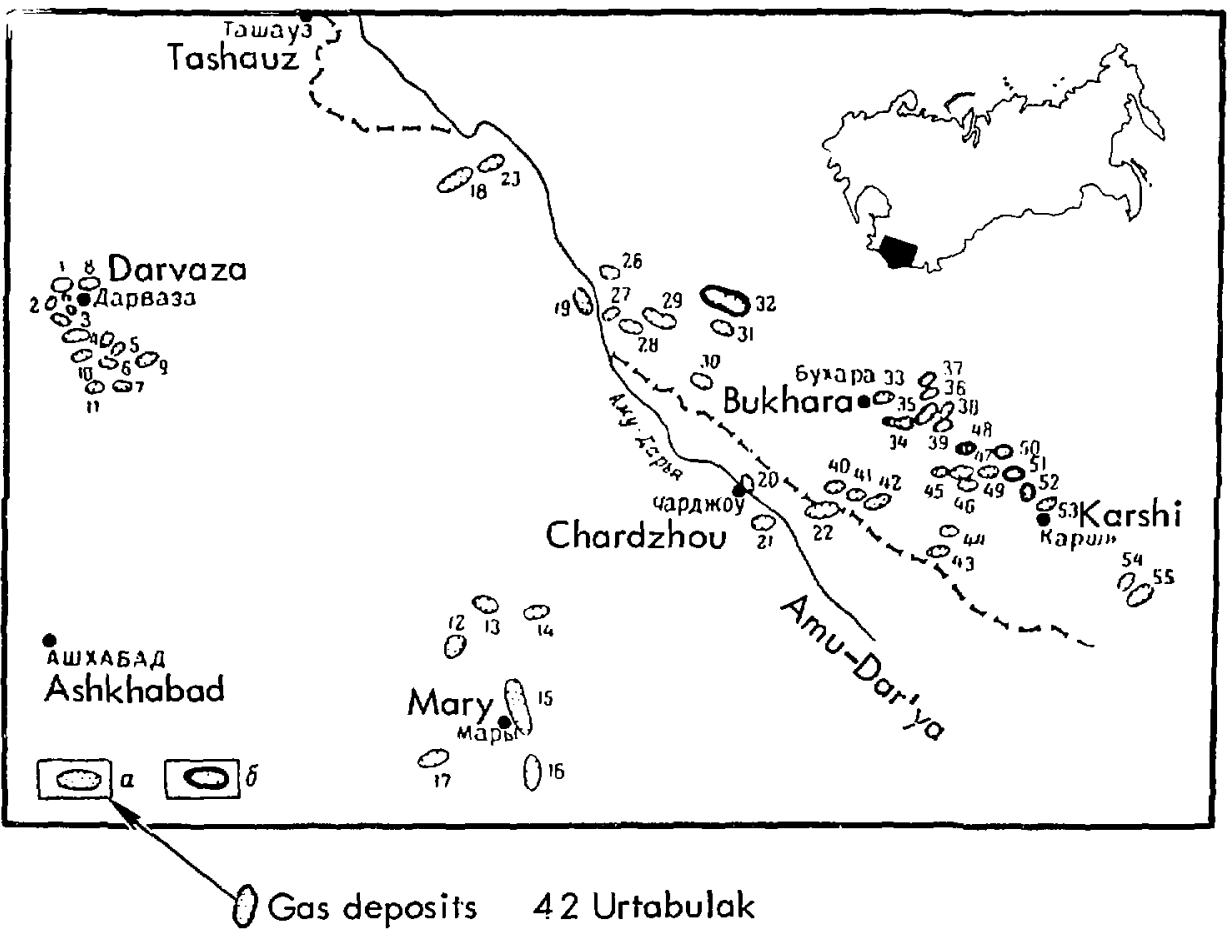

Fig. 16. Location of Urtabulak gas-condtnsate field. 


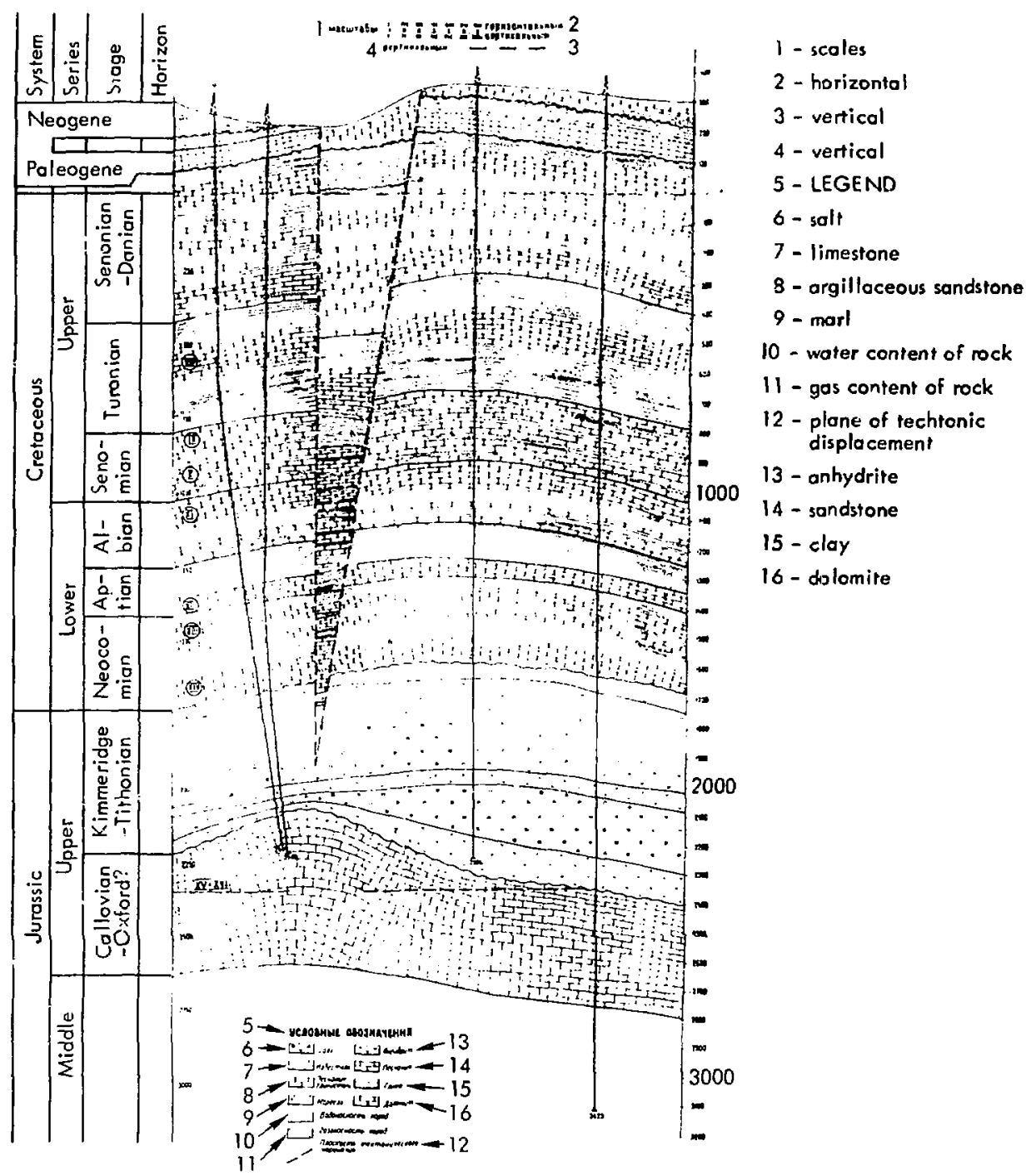

Fit. 17. Crossection of the Urtabulak field in the area of hole No. 11 ,

Many attempls were made during the ensuing timree years to cap the well at the surface or to reduce the flow and extinguish the flame. However, such attempts led to diversion of the gas into other nearby wells and to serious personnel salety problems because of the high $\mathrm{H}_{2} \mathrm{~S}$ content of the gas ( $7.9 \%$ by weight). Over 


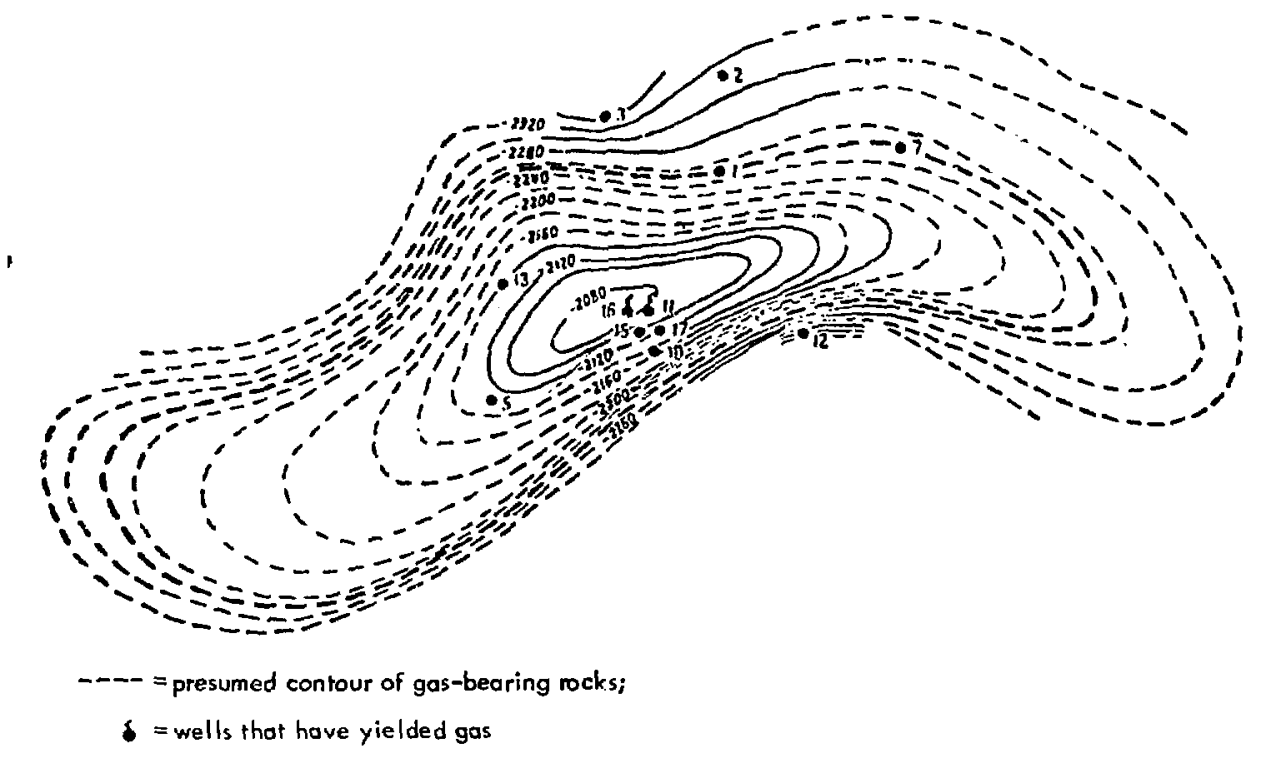

Fig. 18. Structural map along the roof of horizon XV' at Urtabulak field.

2.8 million rubles were lost by the runaway well and the remedial measures taken to seal it in this first year, not counting the loss of gas, which remained at about $12 \times 10^{6} \mathrm{~m}^{3}$ per day. Sealing the hole from an adjacent hole ty means of cement injection or high explosives was not regarded as being feasible because Hole No. 11 had not been surveyed before it got away from control.

Finally, in the fall of $1966,{ }^{12}$ it was deci led to use a nuclear explosive to seal the we!l shut. A slant well was drilled as shown in Fig. 19 to come as close as possible to Hole No. 11 at a depth of about 1500 meters within a 200 meter thick Aptian clay zone, immediately above the XIIth producing horizon in the lower Cretaceous series (see Fig. 17). This drith was considered sufficient to contain the 300-atmosphere formation pressure. Although the distance from the closure well to the runaway well was calculated to be not more than 80 meters, measurements made after the well was drilled using electromagnetic detection of the steel casing and acoustic detection of the escaping gas ${ }^{13}$ led to the belief that the distance was only $35 \pm 5$ meters. ${ }^{4}$ A $30-k t$ explosive was emplaced in the slant well and detonated. Twentysix seconds later the flare went out and the well was sealed. No radioaciirity above background was detected at the surface of the ground during postshot surveys.

Second Field-Also during the fall of 1966, a second runaway gas well (Hole No. 2-R! occurred in a "nearby" gas 


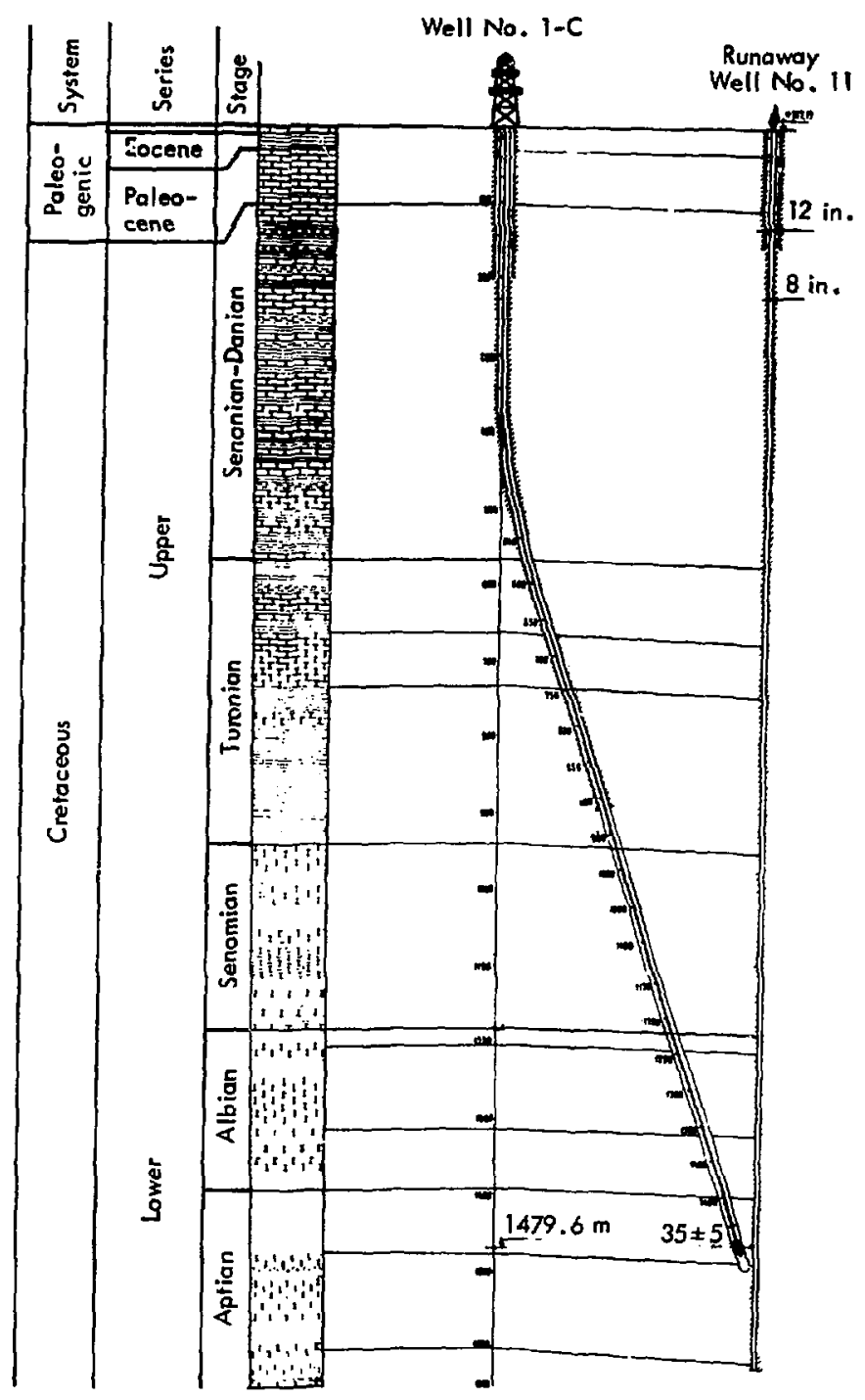

Fig. 19. Profile of special emplacement well drilled to approach runaway Well No. 11 at Urtabulak field.

field with a similar geologic structure resulting in the loss of $1-1.5 \times 10^{6} \mathrm{~m}^{3} /$ day (35-50 MMCF/D). In this case, however, drilling had progressed to a depth of 2748 meters before the XV production horizon was penetrated (see Fig. 20) and significantly higher pressures were encountered (580 atm). A month 


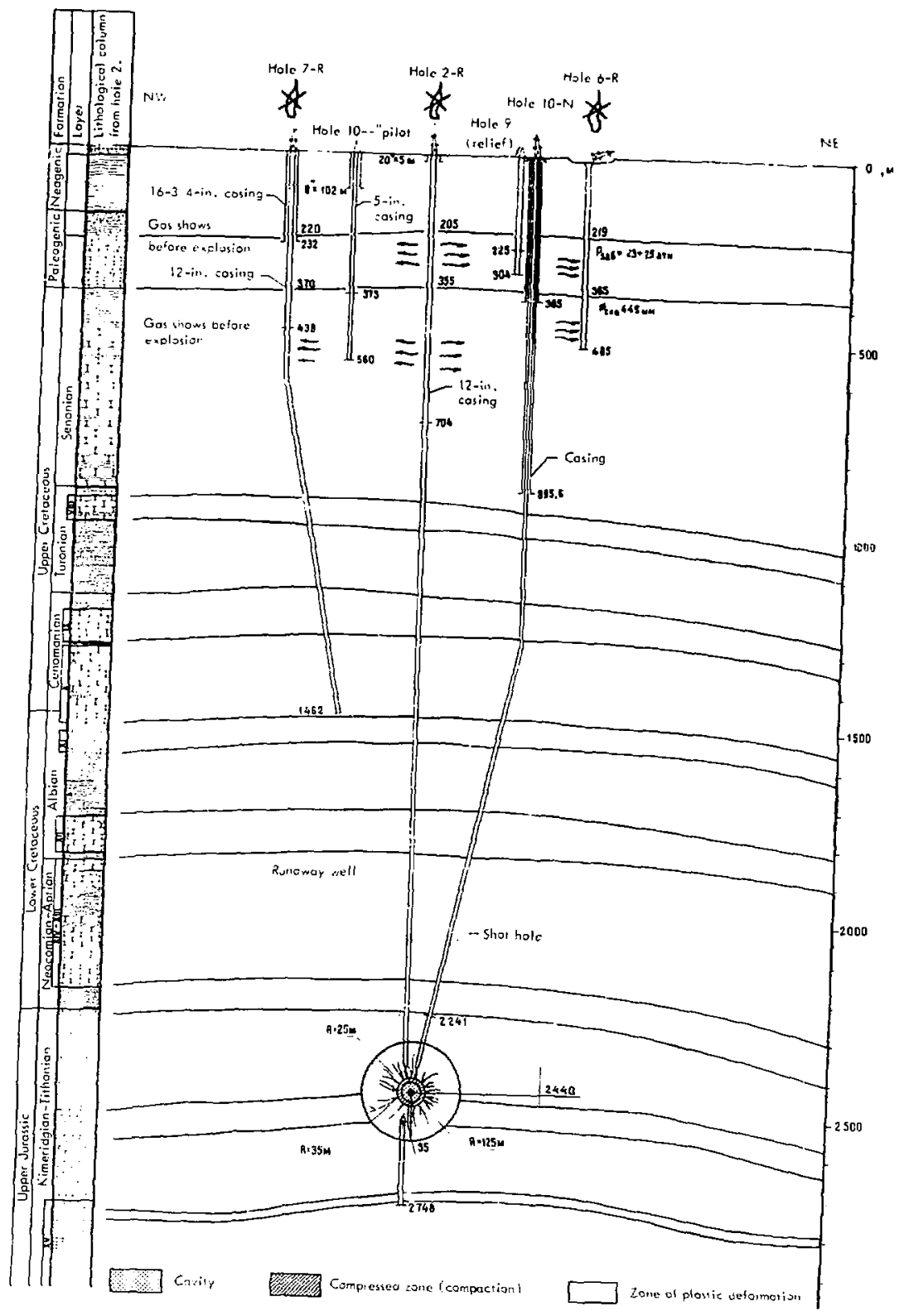

Fig. 20. Profile of "nearby" second field, showing method of emplacement of nuclear
explosive. 
and a half alter the runaway well started, it blocked itself at a depth of about $800-$ 1000 meters. A 12 -inch casing was cemented to a depth of 700 meters and the hole was cleaned out to the top of the producing horizon, surveyed, and a 5-3/4 inch drilling string was cemented in the hole. Four months later, gas started to appear in surrounding wells and even penetrated directly to the surface indicating that the cement job was imperfect and that gas was leaking outside the drill string cemented in the hole.

After unsuccessful attempts to seal the well by hydraulic fracturing from a slant-drilled well, a new slant-drilled well (Hole $10 \mathrm{~N}$ ) was drilled to intersect Hole $2-R$ at a depth of 2440 meters in the Kimeridgian-Tithonian salt formation that overlies production horizon XV. (See Figs, 17 and 20.) Measurements made after the slant-well was $30 \pm 5$ meters away from Hule 2-R. A 40-kt nuclear explosive was placed in Hole 10-N and detonated. Because of the large amount of gas that had been released into the overlying strata during the preceding two years, the flow continued for seven days before it finally died out and the seal was complete. Again, radiation surveys showed no radiation above background in the area. Thus, in the late spring or early summer of $1968^{12}$ the second runaway gas well was sealed by nuclear explosions and the Soviets "concluded with certainty that the method has passed industrial testing and can be recommended in practice." 14

\section{Oil Stimulation}

Experience has shown that the efficiency of recovery of oil from carbonate-type oil depositi is, in general, fairly low $(<40 \%)$. Thus, over half the oil is left in the ground. A number of secondary recovery techniques are practiced with varying degrees of success, depending on the nature of the deposit and the character of the oil. These methods include water and gas injection, fire or hot-water flooding, hydro-fracturing to increase the permeability of the formation, and introduction of gas ints the oil to reduce the viscosity. However, many fields resist such conventional techniques and, in an effort to increase the recoverable reserves, the Soviets have used nuclear explosions for stimulation on a large-scale in at least two different fields.

Field A-The first oil field is shown in plan and in section in Fig. 21. This has been described as a solution gas drive reservoir in which ultimate recovery had been projected at $\sim 25 \%$ of the in-place reserves. $2,3,4,14$ The reservoir is a limestone reef at a depth of 1000-1500 meters overlain by interbedded anhydrite and halite layers. Underneath, the deposit is isolated from a pressurized water zone by a bitumenized or oxidized layer 25-50 meters thick.

Figure 22 shows the total production from this field as a function of time. Production, $Q$, increased rapidly as new holes were drilled during the first three years but then decreased equally rapidly. One reason for this rapid depletion may be the behavior of the gas/oil ratio also shown in Fig. 22. Although initially in the range of $\sim 100 \mathrm{~m}^{3} /$ ton, it rapidly grew to $400-500 \mathrm{~m}^{3} /$ ton as channeling devraloped and the dissolved gas escaped from the 

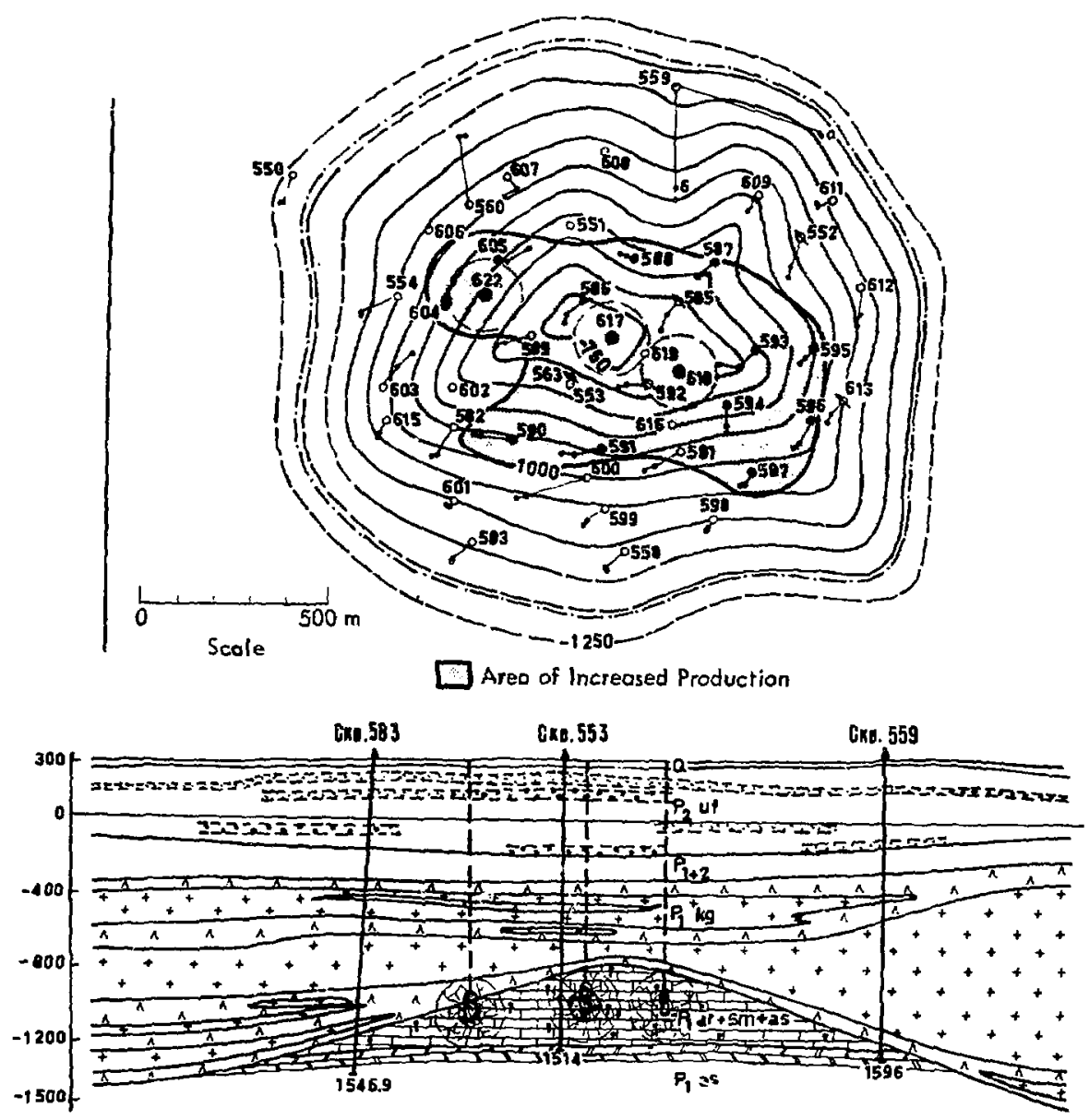

TEST INDUSTRIAL NUCLEAR EXPLOSIONS IN AN OIL FIELD.

- producing wells

- output-increasing wells
6 wells from which gas escaped

(D) nuclear stimulatica wells
++ Solt

$\left[\begin{array}{ll}n \\ n\end{array}\right]$ Anhydrites
$\mathrm{CH \textrm {B }}=$ well

돌 Limestone

YZZ Zone of Oxidized or Bituminized Oil

Fig. 21. Plan and profile of test industrial nuclear explosions in a Field A oil deposit. 


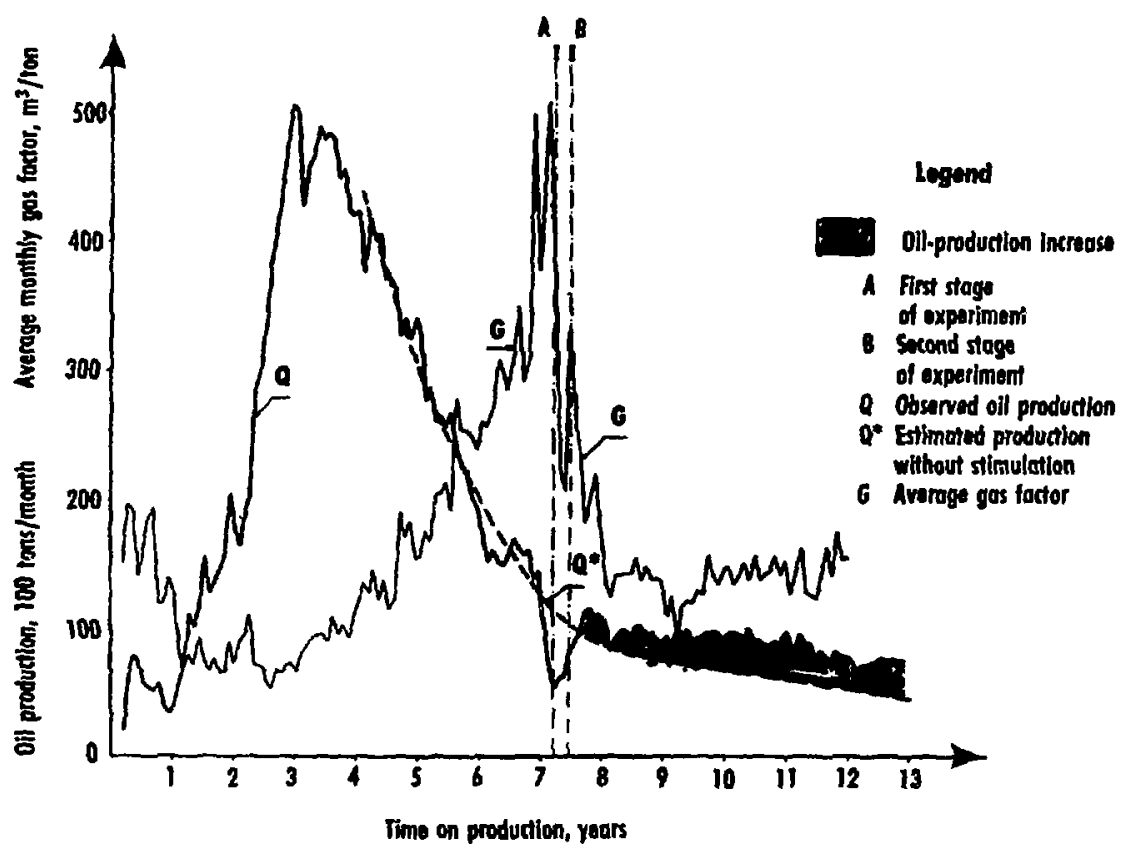

Fig. 22. Production of Field A deposit.

deposit, leaving the oil behind. A similar picture is shown by the plot of formation pressure versus oil recovery factor shown in Fig. 23.

In order to reverse these trends, during the eighth year of production, the Soviets decided to try nuclear stimulation of this field. The first stage involved the detonation of two 2.3-kt nuclear explosives, 200 meters apart at depths of 1378 meters and 1348 meters as shown in Fig. 21. The explosions were not simultaneous but fired close in time. The second stage involved the detonation of a single 8 -kt nuclear explosive 3-1/2 months later, 350 meters from one of the two 2.3-kt charges at a depth of 1350 meters. Prodiucson holes in the vicinity of the shots were sealed during the nuclear operation but were re-opened after the shots and production resumed at the increased rate shown in Figs, 22 and 23. The average rate of production increased $34 \%$ and the projected recovery factor for the field, based on six years postshot data, has been increased by almost 50\% from 25 to $35 \%$. Perhaps most significant is the drop in the gas/oil ratio to $\sim 150 \mathrm{~m}^{3} /$ ton immediately after the shots and its persistence at that level throughout the ensuing five and a half years.

A recent economic analysis of this project by Lawrence Livermore Laboratory, ${ }^{15}$ based on the data provided by the Soviets, using US-type oil drilling and nuclear explosive costs, and assuming 


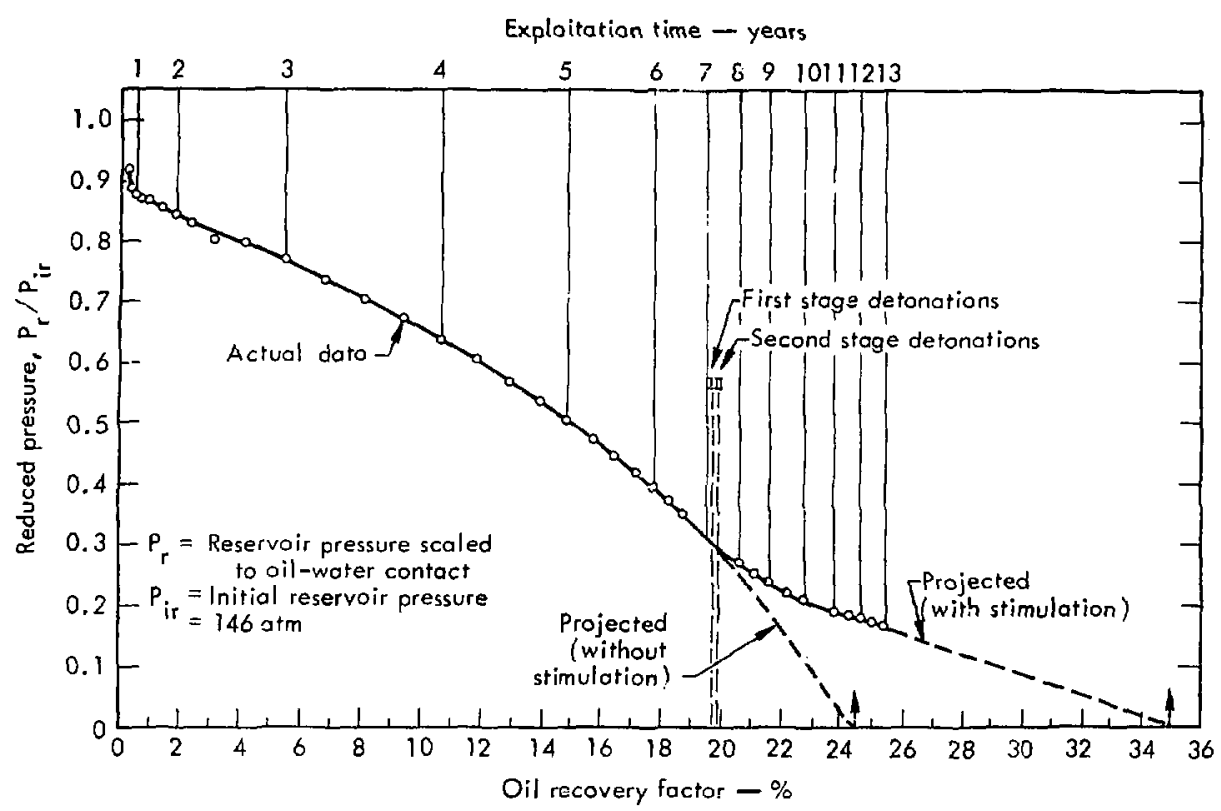

Fig. 23. Formation pressure vs reservoir pressure, with projected curves for with stimulation and without stimulation.

that this project was one of a series of such projects, shows that the internal rate of return would be about $30 \%$.

Alternatively, if such a project were financed at an interest rate of $10 \%$, profits over the life of the project would be about $180 \%$ of the invested capital. A similar economic analysis by Jean Charlon of Geonuclear Nobel Paso ${ }^{16}$ has shown similar results.

Increased production was reported by the Soviets for 20 wells within 300-470 meters of the shot points. The general area of increased production is identified in Fig. 21 by the crosshatchec area. Based on these data showing increased production and the detection of radioactivity in wells, the Soviets believe the general area of fracturing extends as far as 300-400 meters from the shot points, with some individual fractures extending as far as 800 meters. Distances of 300400 meters would correspond to 20-40 times the cavity radii. This corresponds to many times the 4-7 cavity raciij generally reported in the US ${ }^{17}$ and the 3.7 cavity radii reported by the French for the Hoggar granite. ${ }^{18}$ However, it should be pointed out that the only US experience in a carbonate inedium was the Handcar Event ${ }^{19}$ in a dry, fractured dolomite, in contrast to the saturated limestone in the Field A deposit. We would not expect the geologic differences to have that great an effect, but we do not have the appropriate experience.

The Soviets have put forward no specific explanation for the observed 
increase in production other than to point to areas of increased production (see Fig. 21) and infer that it was the result of a widespread set of fractures. We have considered the four possible mechanisms following as possibly contributing to the observed increasc in production:

1. Increased permeability due to widespread fractures induced by the nuclear explosions.

2. Reduction of the viscosity of the petroleum as a result of dissolving $\mathrm{CO}_{2}$ generated by the explosion in the petroleum.

3. Possible maintenance of the reservoir pressure as a result of fracturing through the bitumenized zone below the oil with subs equent encroachment by he high-pressure water underlying the formation.

4. Action of the shock wave in breaking up or disruption of channels developed by the gas which had deve ad over the years and had permitted the gas to escape from the formation without pushing the oil to the production holes.

The first mechanism would be sufficient but it is hard to believe the great distance inferred for the fractures. With regard to the second possible mechanism mentioned above, analysis by Howard ${ }^{20}$ has shown that insufficient amounts of $\mathrm{CO}_{2}$ would be available to explain the increased production on this basis. Further, this would not explain the change in the slope of the pressure vs production curve shown in Fig. 23 nor the sharp drop in the gas/oil ratio in Fig. 23. The third mechanism, use of explosions to fracture the barrier below the reservoir and re- pressurization by the underlying water, is discussed in an article by Babalyan and Ovanesov ${ }^{21}$ as a possible method for secondary recovery of fields of this type. Such a mecharism would well explain the change in the pressure vs production curve in Fig. 23 but it would not appear to have any influence on the gas/oil ratio. The fourth mechanism has been shown in laboratory experiments to be effective 22 and could well extend to the wide area over which increased production has been reported. It also would appear to explain both the change in slopes of the pressure vs production curve and the gas/oil ratio curve. Unfortunately, there is insufficient data on individual well performance to conclusively confirm or deny the role of any of the above iour mechanisms.

Figures 22 and 23, presented at the 8th World Petroleum Congress in Moscow in June 1971, show about five and a half years of data following the nuclear explosicns. Correlation with Fig. 3 in Ref, 4 leads to the conclusion that the two 2.3-kt explosions were fired in March-April and the 8-kt explosion in Jily, 1965, or possibly the same dates in 1964 or earlier. Since that time, oil has continued to be produced from the ficld, has been analyzed to assure that it does not contain harnful amounts of radioactivity, and has been in routine use in the Soviet Union.

Field B-At the World Petroleum Congress, Orudjev, et al., ${ }^{14}$ also described a second oil stimulation project in a carbonate reef deposit similar to the Field A deposit but located at a depth of 1000-1200 meters (see Fig. 24). The oil reservoir is made up of a series of 


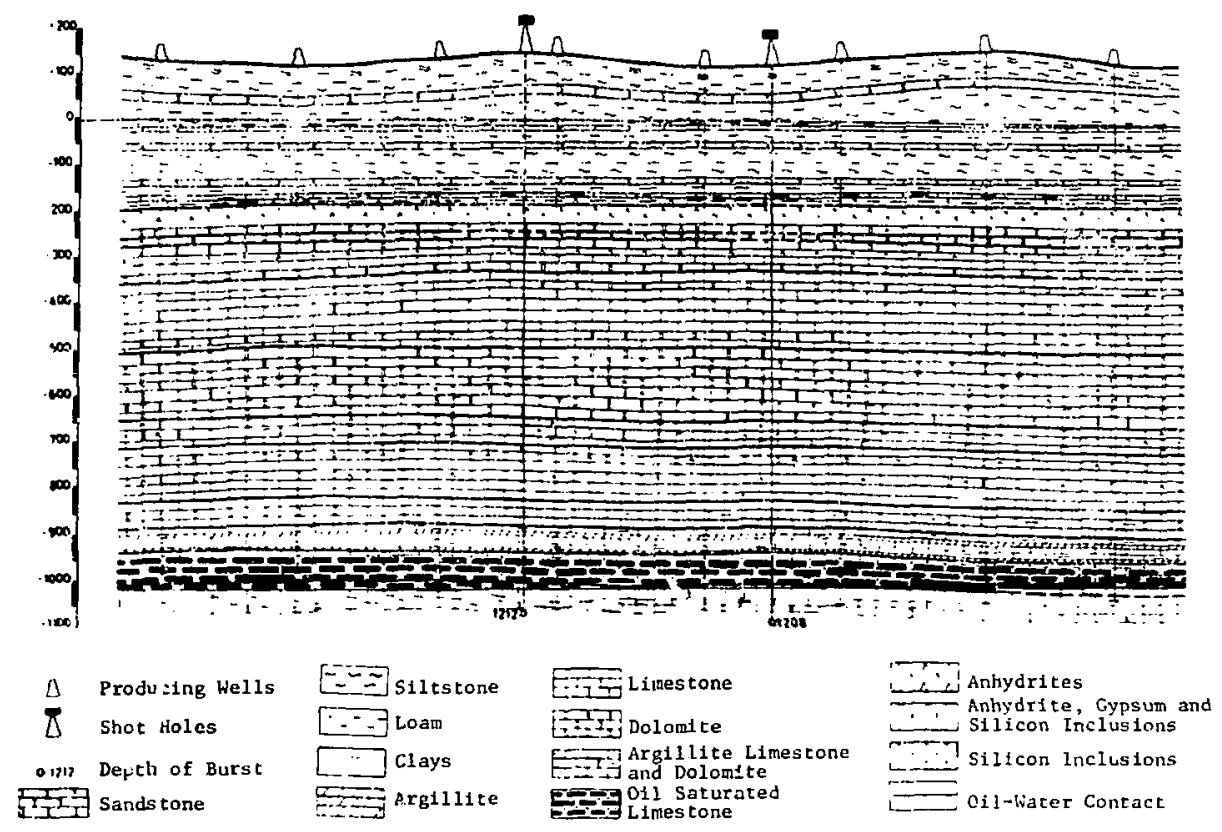

Fig. 24. Profile of Field B oil deposit.

porous, fissured limestones and dolomites up to 110 meters thick. It is underlain by a water-bearing formation with the oil-water contact at an ele:ation of about 1015 meters (depth $\sim 1115$ meters). Immediately overlying the deposit is a cap rock consisting of siliceous and argillaceous limestones and siltstones. Porosities of the oil formation range from 0.5 to $24 \%$ with permeabilities being in the range of 0.1 to 600 millidarcies. Effective thickness of the producing sections is about $50 \%$ of the total section. Oil densities ranged from 0.860 to $0.889 \mathrm{~g} / \mathrm{cm}^{3}$.

This reservoir, however, is significantly different from the Field $A$ deposit in that it was being produced by water injection. Water was being pumped into three rows of wells in the north and south sides of this deposit, driving the oil to the rows of production holes in the center of the field. Initial reservoir pressures were 118 atm but had declined to 50-60 atm due to depletion of the field. Bottomhole pressures had devlined to only 2235 atm and oil was being pumped from the holes.

In an attempt to stimulate the production from this field, two $8-k t$ nuclear explosions were detonated in the middle of the field as shown in Fig. 24. The first explosive was detonated at a depth of 1212 meters which put it in the limestone and dolomite layers about 140-144 meters below the top of the oil reservoir 
and about 30 meters below the oil-water contact. Although not discussed, it is presumed that the chimney extended upward into the oil-bearing formation. The second explosion was detonated some time later at a depth of 1208 meters, also below the oil-water contact, some 1200 meters away from the first shot. The first shot was 150 meters from the nearest producing well while the second was 300 meters from the nearest producer.

Although no production data have been published by the Soviets, they have stated their conclusion, after a year or more of postshot production, that the seven producing wells in the range from 150 to 800 meters from the explosions increased their production by 30 to $60 \%$. There is also evidence to indicate that the rate of water flow within the formation has also been increased. There was no increase in pressure in the field nor was there any escape of radioactivity to the atmosphere. The radioactivity appearing in the oil was insignificant and the oil was put inio general use several days after the explosions. Here again, extraordinary fracture radii are reported and credited with stimulating the flow of oil. Unfortunately, insufficient data is available to make any kind of evaluation of the Soviet claims.

For their part, the Soviets feel that these two industrial scale experimental tests have 1) provided valuable technical data on the effects of nuclear explosions in carbonate hydrocarbon reservoirs, 2) demonstrated that such explosions can be carried out safely and with minimal seismic damage, and 3) confirmed the ability of nuclear explosions to fracture large areas of such carbonaceous reser- voirs with a subsequent significant increase in production.

Proposed Field $C-$ The Soviets have also discussed a proposal for an additional oil stimulation project as shown in Fig. 25. In this formation is another carbonate reef about 100 meters thick lying at a depth of about 1400-1520 meters. The deposit overlies a righ pressure limestone water zone which is screened from the oil formation by dense intercalations. Although the nature of the screen is different than those considered by Babaly an and Ovanesov ${ }^{21}$ and those encountered at Field $A$, the solution proposed is similar: three nuclear explosions in the range of 20-30 kt, placed in the center of the deposit some 20-30 meters below the oil-water contact. The fractures and ehimneys would break through the intercalated zone an.l permit the water to invade the reservoir and push out the oil.

\section{Gas Stimulation}

On several occasions, Kedrovskiy has stated that the Soviets have carried out a nuclear gas stimulation experiment, 2,3 but no details have been made available. They have, however, proposed the following nuclear gas-condensate stimulation projects.

\section{Proposed Nuclear Gas Stimulation} Project - This project involves a gascondensate reservoir in the carbonaceous reef deposit shown in Fig. 26. The 400 meters of section between 1200 meters and 1600 meters contains the gas deposits with a heavily oxidized oil zone lying between 1600 and 1700 meters. Below 

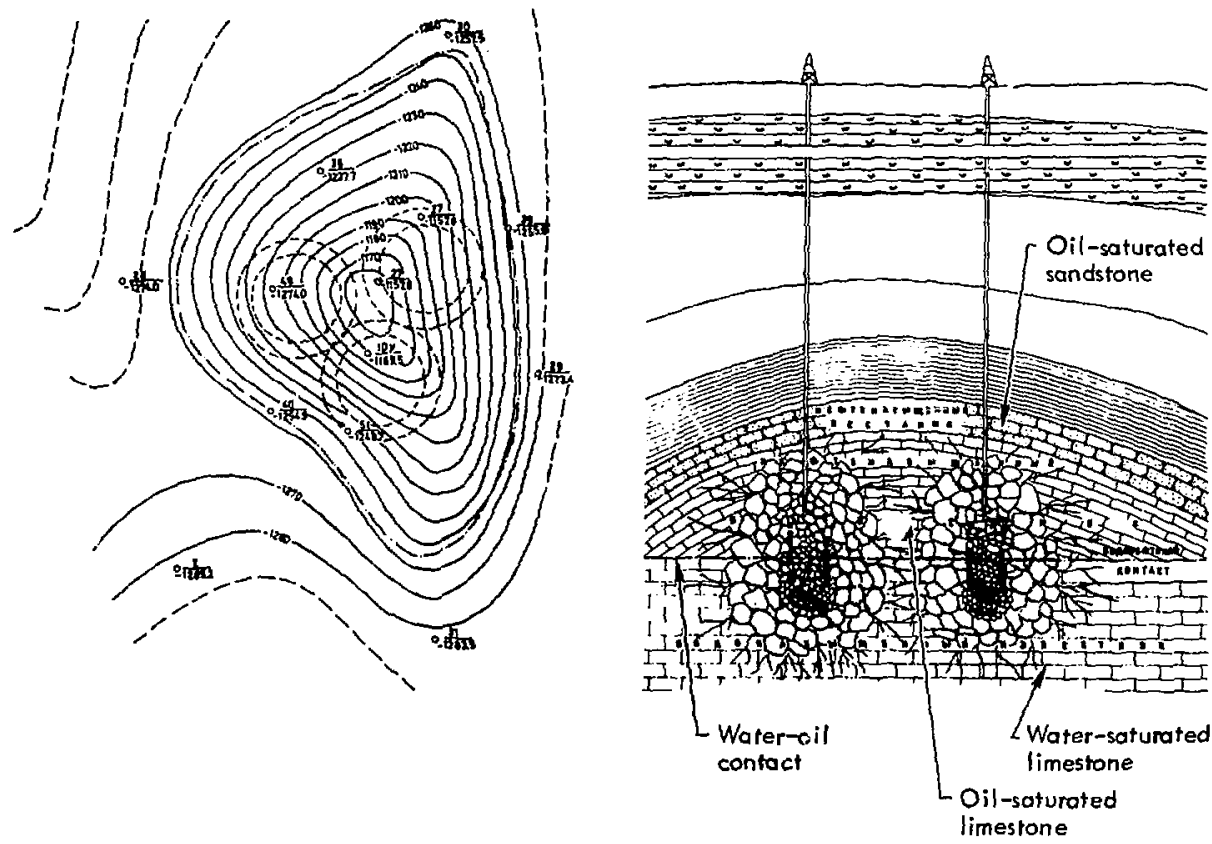

Fig. 25. Scheme for using explosions in oil deposits with underlying water.

the oil is a water zone. Experimental plans call for the detonation of three 40-kt nuclear explosives at depths of 1600 meters in the center of the northern massir, each producing a zone of intense fracturing with a radius of 270 meters which corresponds roughly to 8-12 cavity radii. Gas production is expected to increase from $0.25 \times 10^{6} \mathrm{~m}^{3} /$ day $(8.8$ $M M C F D)$ to $3 \times 10^{6} \mathrm{~m}^{3} /$ day (106 MMCFD).

\section{Underground Storage of Gas and Oil}

Underground storage is a technicalindustrial methodology in which the Soviets have expressed a great deal of interest and placed a large effort. ${ }^{4,23}$ Applications of interest include not only storage of gas, oil, and LNG, but also the storage of biologically harmful wastes. Their analyses have shown that gas can be stored in nuclear cavities for one sixth the cost of surface LNG storage and one third the cost of washed cavity storage. Gas condensate can be stored in nuclear storage for one eighth the cost of surface storage and one fourth the cost of washed cavities. Such comparisons would appear to be consistent with the many cost studies that have been made in the US, ${ }^{24,25,26}$ the UK, ${ }^{27}$ and France. ${ }^{28}$ To support their interest, the Soviets have described two nuclear experiments they have carried out, the industrial testing of a nuclear cavity, and two other applications they are studying. 


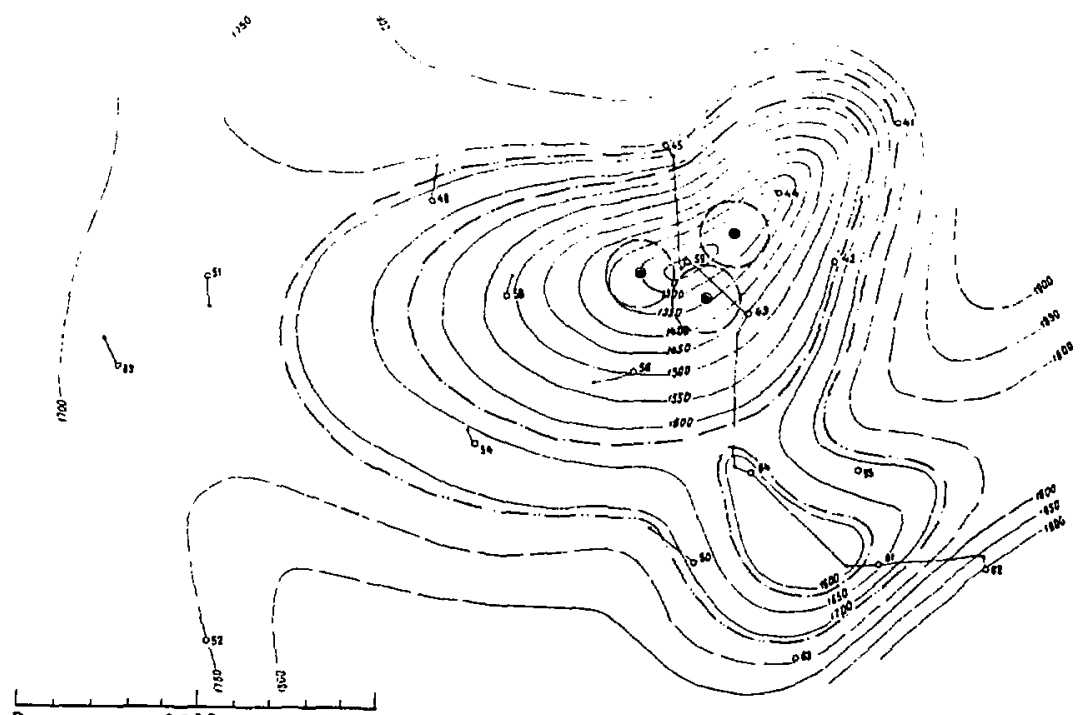

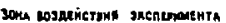

ZONE OF STIMULATION OF THE EXPERTMENT

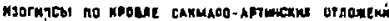

CONTOUR OF THE TOP OE THE SAKMARO-ARTINSK DEPOSIT

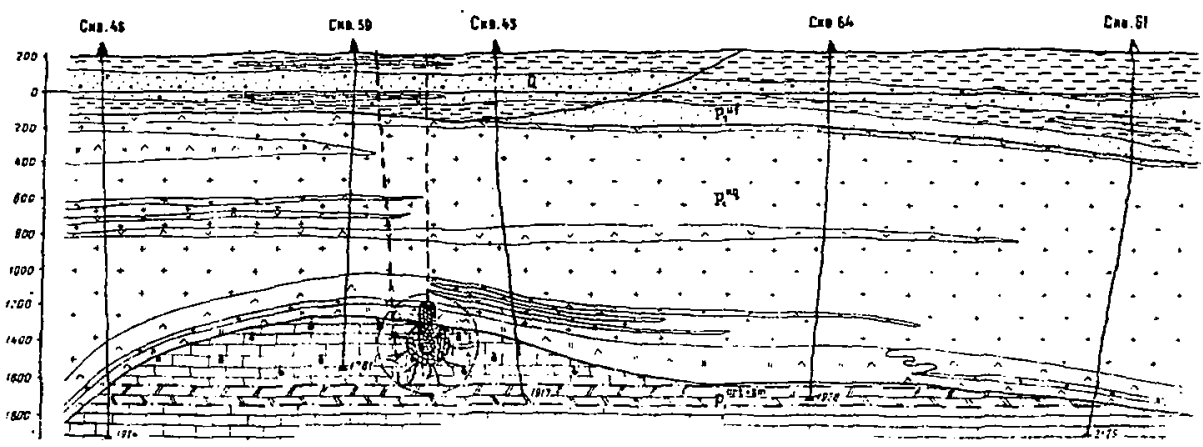

2: 1 Horizontal exaggeration

TEST OF THE GAS-CONDENSATE FORMATION

Puc.7. OMGTHAE TASOKOHAEHEATMDE NECTMOMAEHKE

Fig. 26. Plan and profile of gas-condensate deposit.

1.1-kt Explosion in Salt-This explosion was carried out at a depth of 161.4 meters in a salt dome that penetrated very near the surface of the eartl. (see Fig. 27). An ellipsoidal cavity was formed which had a volume of about 

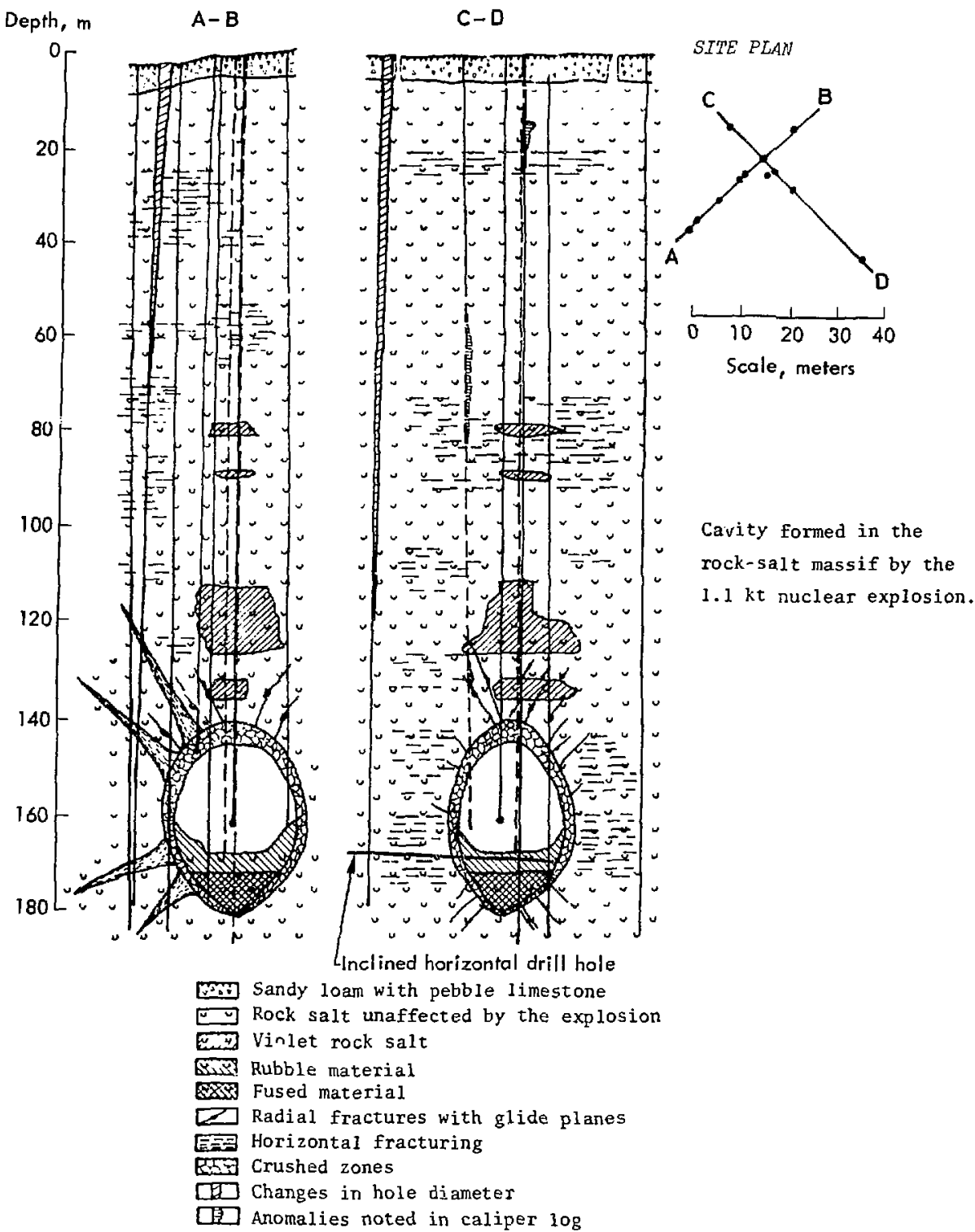

Fig. 27. Cavity formed in the rock salt massif by the 1.1-kt nuclear explosion. 
$11,200 \mathrm{~m}^{3}$ and a radius in the horizontal direction that ranged from 12 to 14 meters. A zone of crushed salt 1.5 to 6 meters thick surrounded the cavity. Shortly after the explosion, the cavity filled with water and some $8000 \mathrm{~m}^{3}$ of rubble fell from the top of the cavity. During the operation, some 13 holes were drilled for exploration of the cavity and the surrounding medium, six of which penetrated the cavity. Cavity measurements were made with the aid of borehole acoustic sondes and television cameras. The Soviets reported no radioactivity escaped to the surface although some radioactive products were detected in exploratory holes, indicating the presence of fractures. Fractures to 29 meters below the cavity and 35 meters in a horizontal direction were detected, corresponding to between two and three cavity radii. Fractures and radioactivity were detected 85 to 100 meters above the shot but were almost certainly associated with the presence of the emplacement and exploratory drill holes. Leakage of the water into the cavity probably resulted from breakage of the seals and cementing in the emplacement hole and explorator; holes by surface spall which was observed to be 2 meters at ground zero.

\section{5-kt Explosion in Salt-In a nearby} location, a 25-kt explosion was later detonated in a salt dome at a depth of E. i meters. In this case, the salt dome was overlain by an anhydrite and gypsum cap about 60 meters thick and 250 meters of sandy argillaceous deposits (see Fig. 28). The cavity resulting from the explosion was almost spherical with a radius of about 32 meters and a volume of about
$140,000 \mathrm{~m}^{3}$. Reentry to the cavity was made through the emplacement hole as well as by two postshot holes as shown in Fig. 28. Fracturing in the region of the cap rock was noted as indicated in Fig. 28 which resulted from reflection of the shock by the change in acoustic impedance properties between the cap rock and the overlying sedimentary deposits.

This latter cavity is very similar to the 5-kt Salmon cavity ${ }^{29}$ produced in the US, but, because of the larger yield and shallower depth (590 vs 828 meters), it was about 8 times larger. Both appear to have a puddle of resolidified salt and explosive debris in the bottom of the cavity that is $0.35-0.4$ crater-radii deep. Scaling the 17.4 meter radius of the Salmon cavity to $25-k t$ at 590 meters gives a radius of 33 meters, in excellent agreement with the observed 32 meters for the Soviet cavity. Scaling of the Salmon radius to 1.1 -kt at 161 meters gives a radius of 17.5 meters, significantly larger than the 12 to 14 meters observed for this shot. No reason is readily apparent for this discrepancy.

\section{Industrial Testing of a Nuclear Storage} Cavity-The Soviets have reported the industrial testing of one of their nuclear cavities with both oil and gas. ${ }^{23}$ They found that the effective volume for storing liquefied gas condensate was $10 \%$ larger than its geometrical volume. For gas its

\footnotetext{
* The radius and volume of this cavity have been reported as being 35 meters and $160,000 \mathrm{~m}^{3}$ in an earlier report, 4 but the numbers given above are the latest available. 23
} 
Projection in plone $\mathrm{I}-\mathrm{I}$

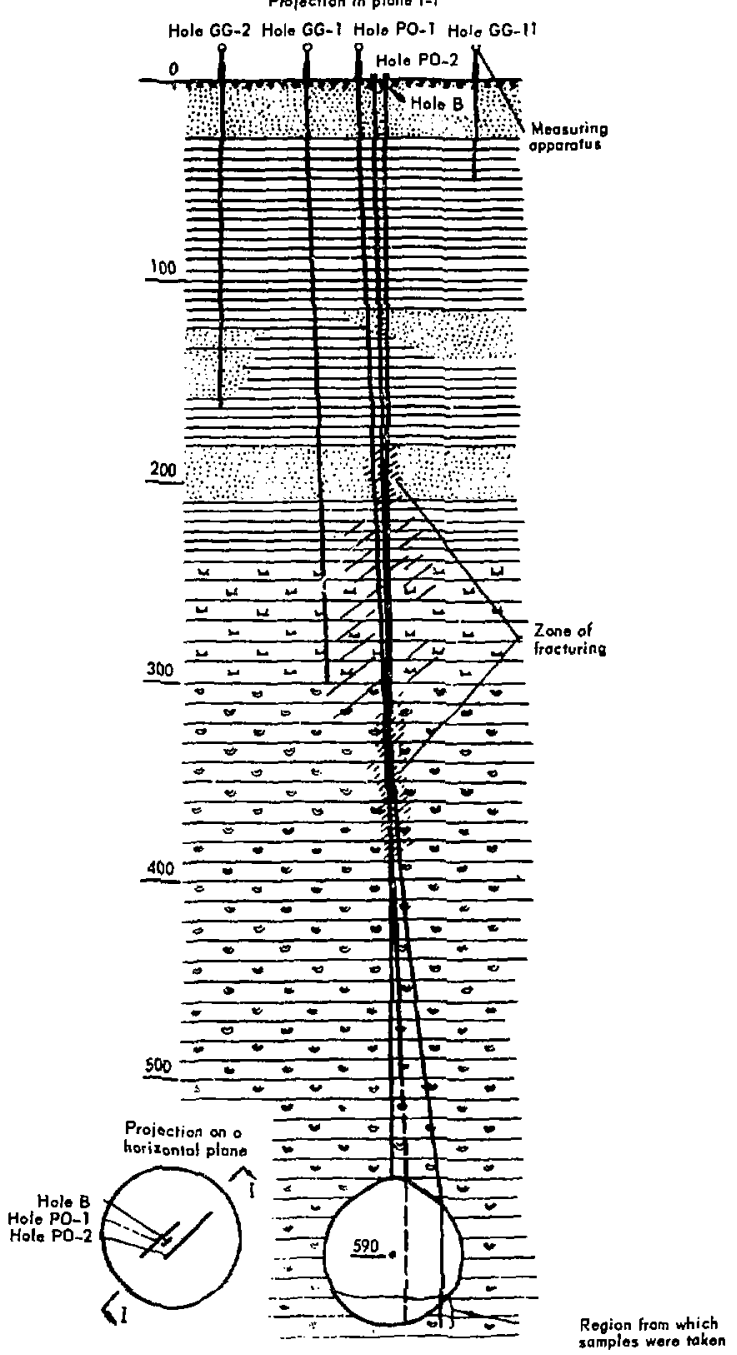

Fig. 28. Profìle of 25-kt explosion in a "nearby". salt dome.

effective volume at $60 \mathrm{~atm}$. was $24 \%$ larger than the geometrical volume. This additional volume presumably results from the porosity of the fracture system connected with the cavity. Con- tamination of the stored product was found to be below the level of concern. This cavity is now reported to be in prototype industrial use on a routine basis. 
Proposed Gas Condensate Storage in Salt-This proposal, shown in Fig. 29, calls for the detonation of two $35-\mathrm{kt}$ nuclear explosives at a depth of 810 meters in a bedded salt formation to produce $300,000 \mathrm{~m}^{3}$ of storage for gas condensate. In order to ensure that the creation of the second cavisy would not destroy the first, they are planned to be spaced at least 800 meters apart.

\section{Proposed Gas Storage in Welded Tuff-} The second proposed storage project calls for the detonation of three 40-kt nuclear explosives spaced 200 meters apart at a depth of 710 meters in a welded tuff section. At this particular site, there is a layer of permafrost from the surface down to a depth of 190 meters. Assuming storage at hydrostatic pressure of 70 atmosphere, these three shots are expected to produce $360,000 \mathrm{~m}^{3}$ of storage, each which will permit storage of
$70,000,000 \mathrm{~m}^{3}$ (2.5 BCF $)$ of gas. Fig. 30 illustrates this proposed application.

Mineral Development

In order to determine the parameters of a contained nuclear explosion in hard rock, the Soviets reentered the chimney and fracture zone of a nuclear explosion in granite. A cross section and plan view of this reentry work and the results of their studies and measurements are shown in Fig. 31. The actual yield or depth of burial have not been given. They found a scaled cavity radius of about $10-15 \mathrm{~m} / \mathrm{kt}^{1 / 3}$ and a chimney height of $4-5$ cavity radii. Sur rounding the cavity was a crushed zone extending from the cavity to a scaled radius of $20-35 \mathrm{~m} / \mathrm{kt}^{1 / 3}$ which corresponds to about 2-3 cavity radii. A zone of fracturing, probably resulting from tensile failure extending to a scaled radius of $50-70 \mathrm{~m} / \mathrm{kt}^{1 / 3}$ (4-6 cavity radii) was also observed.
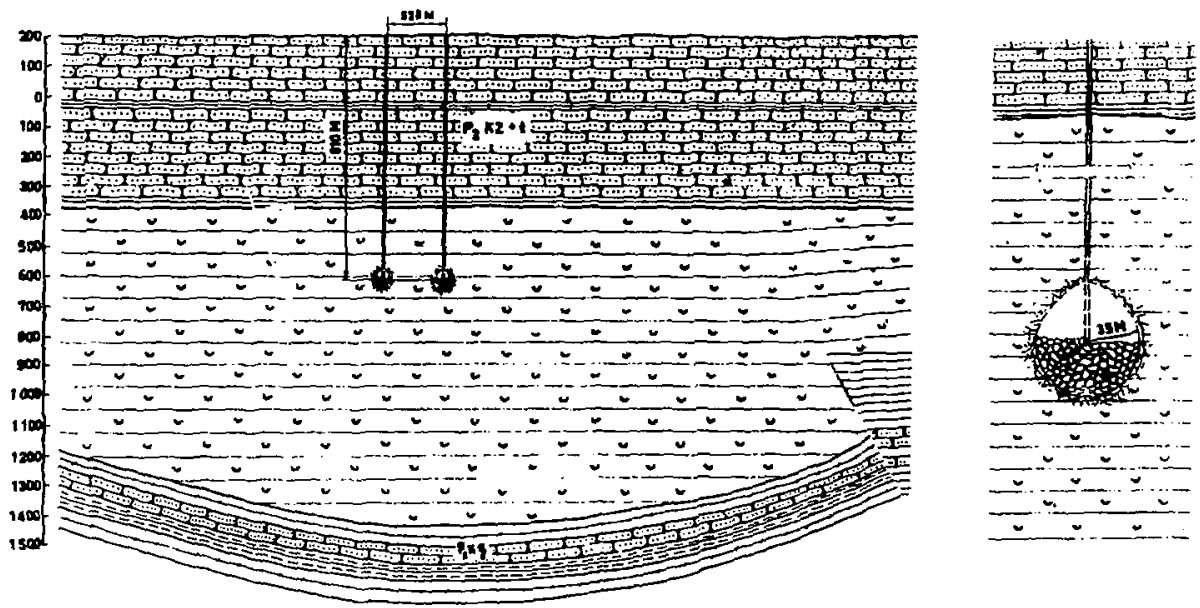

Fig. 29. Scheme for creating storage for gas-condensate in thick rock salt layer. 


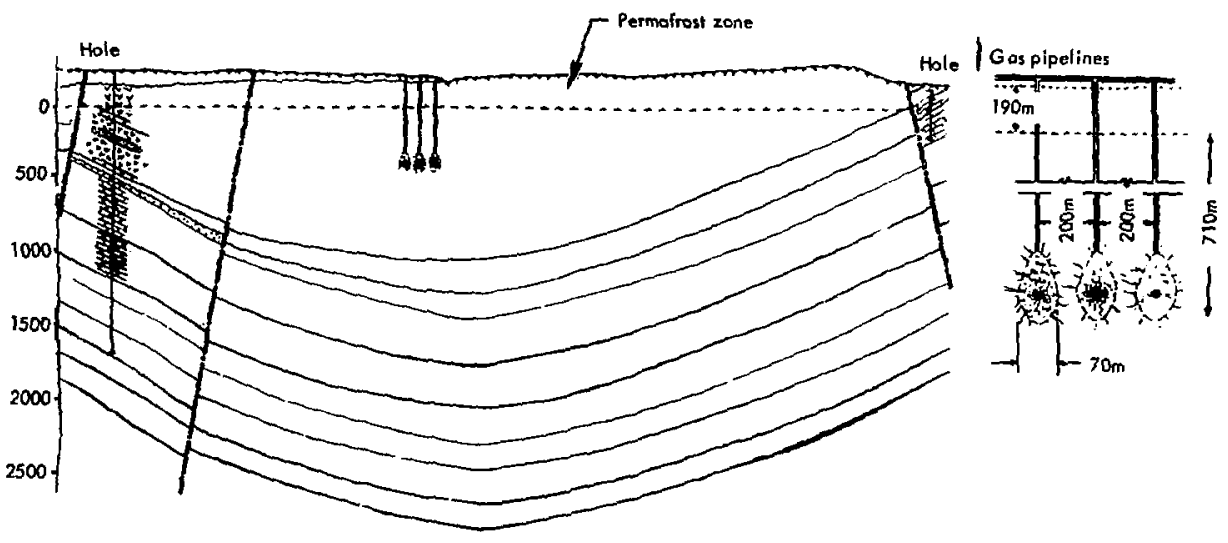

Effusive rock

Limestone, dolomire, marl, asgillite

TuFf

Sandstone

Fig. 30. Profile for proposed gas storage in welded tuff.

Fractures into which melt from the cavity had been injected were noted out to distances of 5 cavity radii.

These dimensions are fairly consistent with corresponding dimensions for the US nuclear explosion in granite, ${ }^{17,30}$ the 5-kt Hardhat and the 61-kt Piledriver Events. Both the US and USSR data on scaled cavity radii are significantly larger than those reported by the French ${ }^{31}$ for the very strong, massive and dry Hoggar granite. However, the zones of compressive failure and tensile failure agree quite well with the Soviet data. The following table compares the Soviet experience in granite with that of the US and the French:

\begin{tabular}{lcccc}
\hline & USSR & Hardhat & Piledriver & French \\
\hline $\begin{array}{c}\text { Final scaled radius of cavity } \\
\left(\mathrm{m} / \mathrm{kt} / \mathrm{S}^{2}\right)\end{array}$ & $10-15$ & 11 & 10 & 7.3 \\
$\begin{array}{c}\text { Maximum scaled radius of } \\
\quad \text { compressive failure }\left(\mathrm{m} / \mathrm{kt}^{1 / 3}\right)\end{array}$ & $20-35$ & 32 & 28 & 26 \\
$\begin{array}{c}\text { Maximum scaled radius of } \\
\text { tensive fractures }\left(\mathrm{m} / \mathrm{kt}^{1 / 3}\right)\end{array}$ & $50-70$ & 85 & 80 & $71^{\mathrm{a}}$ \\
\hline
\end{tabular}

${ }^{a}$ As reported by Derlich, ${ }^{31}$ the tensile fracture zone in the Hoggar massif consisted of an inner zone from 26 to $35 \mathrm{~m} / \mathrm{kt}^{1 / 3}$ which evidenced sufficient residual stress that postshot cores spontaneously broke when removed and an outer zone evidenced by changes in the velocity of seismic waves. 

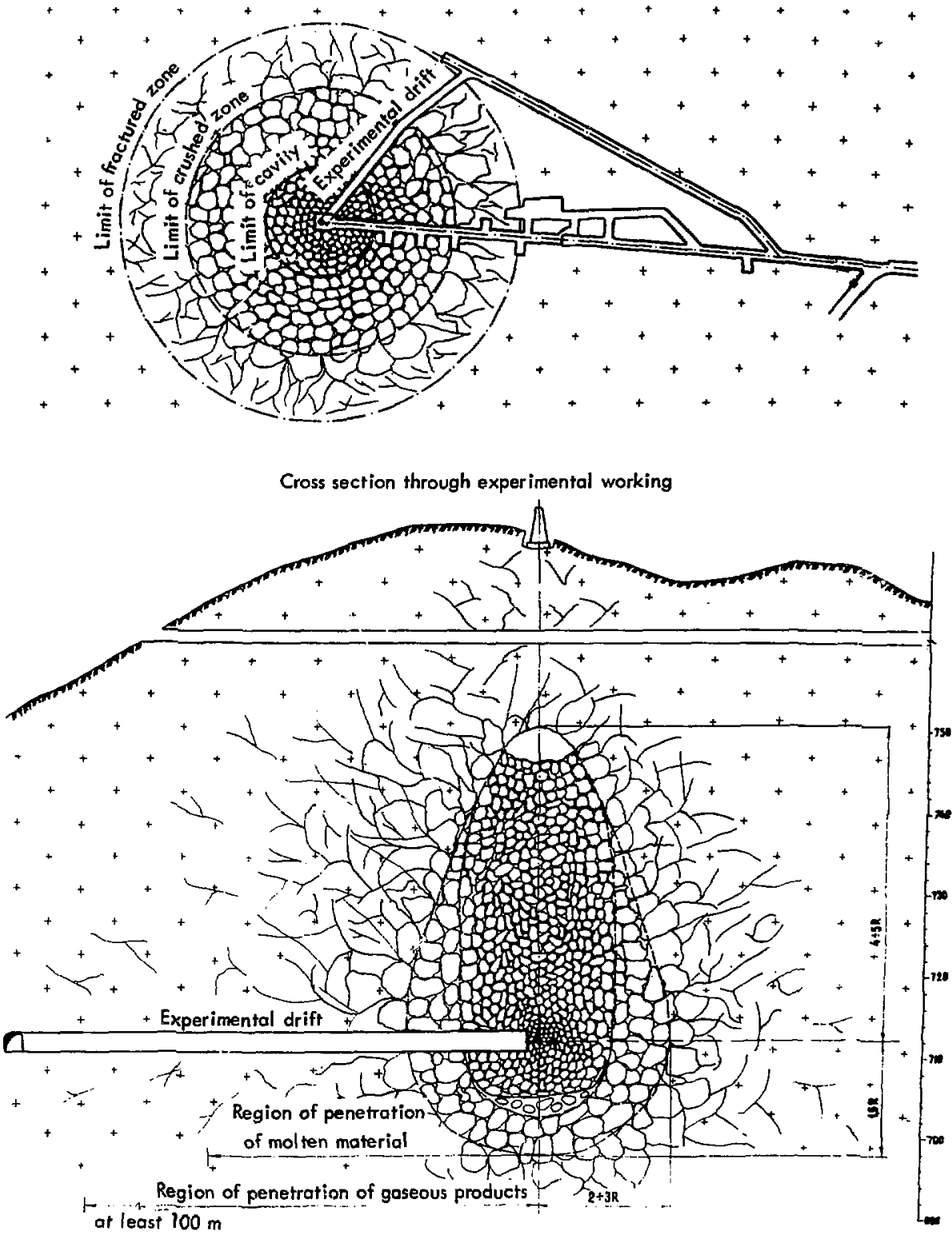

Fig. 31. Plan and profile views of reentry into chimney and fracture zone resulting from nuclear explosion in hard rock. 


\section{Proposed Ore Breaking Project-Ap-} plying the above data on rock fracturing to a useful prupose, the Soviets have described a proposed ore breaking project depicted in Fig. 32. In this project, a 1.8-kt nuclear explosive will be emplaced immediately below an ore body 60-80 meters thick dipping into a mountain at about a $25-35^{\circ}$ angle. To enhance the natural fracture pattern, a vertical and a horizontal lattice-work grid will be mined at distances of $40-60 \mathrm{~m} / \mathrm{kt}^{1 / 3}$ from the explosion. These will provide free surfaces within the mountain off of which the shock wave will reflect as tensile wave, resulting in enhanced fracturing of the rock. The effect of reflection from the sloping free surface of the mountain is also indicated in Fig. 32 . It is expected that this single $1.8-\mathrm{kt}$ explosion will break about $0.9 \times 10^{6} \mathrm{~m}^{3}$ of ore of which $0.4 \times 10^{6} \mathrm{~m}^{3}$ can be removed from an adit below the fracture zone by normal stope-mining methods.

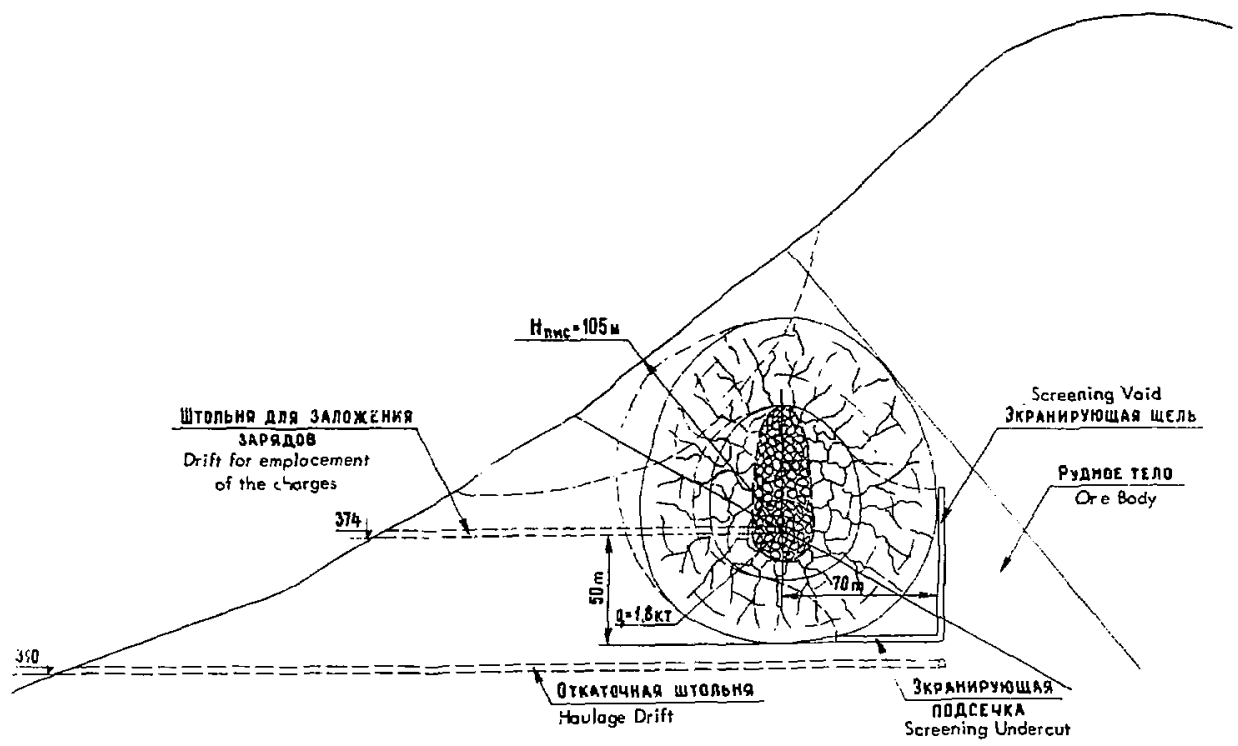

Fig. 32. Scheme for mining an ore deposit with the use of nuclear explosions. 


\section{Seismic Events in the Soviet Union Presumed to be PNE Explosions}

Over the last 10 years or so, a large number of seismic events in the Soviet Union have been reported which are generally believed by a number of observers to be nuclear explosions, based on their location in aseismic areas, the magnitude and the characteristics of their seismic signals (i. e, very small S-wave relation to the $P$-wave). The Stockholm International Peace Research Institute (SIPRI) has published a list of seismic events in the Soviet union that they have presumed to be nuclear explosions and which, because of their location away from the normal test sites at Novaya Zemlya aid Semipalatinsk, they have also presumed are related to the Soviet PNE program. ${ }^{32,33}$ In addition, the USAEC has from time to time announced detection of seismic signals from sites in Russia that are "presumably from Soviet underground nuclear tests." 34

Table 3 summarizes the presumed nuclear events identified by SIPRI and the USAEC which are located away from the normal Soviet test site. Also given in
Table 3 are data on origin time, location, seismic magnitude, and epicenter depth as calculated by the US National Earthquake Information Service (NEIS) from data collected by the World-Wide Network of Standard Seismographs and published in Earthquake Data Reports. 35 Although the Earthquake Data Reports give the location of these events to within 0.001 degree, and indicate precision of $\pm 4-6 \mathrm{~km}$, the locations given in Table 3 are felt to be accurace to within only a "few tenths of a degree" or a few tens of kilometers.

Figure 33 is; a map of the Soviet Union showing the general location of these events. The squares on Novaya Zemlya at the top and near Semipalatinsk on the right represent areas having a large is the : ormal weapons test areas in the Soviet Union. The large number of events and their widespread geographical distribution suggests that the Soviets are carrying through on their announced plans for a broadbased, diversified PNE program.

\section{Summary}

The Soviet PNE program appears to be very broadly used to assist in the development of their national resources with a number of technical areas being developed simultaneously. The technical results they have reported are very encouraging and, in general, comparable or, in some cases, much more favorable than US experience, However, the US experience is much more limited in the types of applications and the geological materia?'s we have investigated. Thus, the technical results and the industrial experience of the Soviets, to tne extent they have been made availabie, have been very useful to the US PNE program.

As indicated in Tables 1 and 2, the Soviets have described in varying detail 
Table 3. Presumed nuclear events in the Soviet Union occurring away from normal test sites.

\begin{tabular}{|c|c|c|c|c|c|c|c|c|c|}
\hline \multirow{3}{*}{$\begin{array}{l}\text { Ident. } \\
\text { Number }\end{array}$} & \multirow[b]{3}{*}{ Inate } & \multicolumn{5}{|c|}{ NEIS ${ }^{a}$ or SIPRI ${ }^{b}$ data } & \multirow{2}{*}{\multicolumn{2}{|c|}{$\begin{array}{c}\text { Event identified } \\
\text { as presumed } \\
\text { explosion by: }\end{array}$}} & \multirow[b]{3}{*}{ Location } \\
\hline & & & Lat & ong & Mla & th & & & \\
\hline & & $\operatorname{time}(G, M T)$ & ON & ${ }^{2} \mathrm{E}$ & $\mathrm{Mb}_{\mathrm{b}}$ & $(\mathrm{km})$ & SIPRI & USAEC & \\
\hline $\begin{array}{l}1 \\
2 \\
3 \\
4 \\
5 \\
6\end{array}$ & $\begin{array}{l}65-01-15 \\
66-04-22 \\
66-09-30 \\
67-10-06 \\
6 H-05-21 \\
64-07-01\end{array}$ & $\begin{array}{l}05: 5: 7: 59 \\
02: 56: 04 \\
05: 59: 53 \\
07: 00: 03 \\
03: 59: 12 \\
04: 02: 02\end{array}$ & $\begin{array}{l}49.89 \\
47.86 \\
38.8 \\
57.69 \\
38.916 \\
47.922\end{array}$ & $\begin{array}{l}78.97 \\
47.72 \\
64.5 \\
65.27 \\
65.159 \\
47.950\end{array}$ & $\begin{array}{l}6.0 \\
+.9 \\
5.1 \\
4.7 \\
5.4 \\
5.5\end{array}$ & $\begin{array}{r}0 \\
0 \\
33 \\
N \\
13 \\
N\end{array}$ & $\begin{array}{l}\text { No } \\
\text { Yes } \\
\text { Yes } \\
\text { Yes } \\
\text { Yes } \\
\text { Yes }\end{array}$ & $\begin{array}{l}\text { Yes } \\
\text { No } \\
\text { No } \\
\text { No } \\
\text { No } \\
\text { Yes }\end{array}$ & $\begin{array}{l}\text { Semipalatinsk area } \\
\text { North of Caspian } \\
\text { Bukliara } \\
\text { East of Urals } \\
\text { Bukhara } \\
\text { North of Caspain }\end{array}$ \\
\hline $\begin{array}{l}7 \\
8 \\
9\end{array}$ & $\begin{array}{l}69-09-02 \\
69-09-06 \\
69-09-26\end{array}$ & $\begin{array}{l}04: 59: 57 \\
04: 59: 56 \\
06 \cdot 59: 56\end{array}$ & $\begin{array}{l}57.415 \\
57.365 \\
45.890\end{array}$ & $\begin{array}{l}54.860 \\
55.108 \\
42.472\end{array}$ & $\begin{array}{l}4.9 \\
+.9 \\
5.6\end{array}$ & $\begin{array}{l}0 \\
0 \\
0\end{array}$ & $\begin{array}{l}\text { Yes } \\
\text { Yes } \\
\text { Yes }\end{array}$ & $\begin{array}{l}\text { No } \\
\text { Yes } \\
\text { Yes }\end{array}$ & $\begin{array}{l}\text { Urals Region } \\
\text { Urals Region } \\
\text { West of Caspian }\end{array}$ \\
\hline 10 & $69-12-06$ & $07: 02: 57$ & 43.832 & 54.783 & 5.8 & 0 & Yes & Yes & East of Caspian \\
\hline 11 & $70-06-25$ & $04: 59: 52$ & 52.201 & 55.692 & 4.9 & 0 & Yes & No & North of Caspian \\
\hline $\begin{array}{l}12 \\
13\end{array}$ & $\begin{array}{l}70-12-12 \\
70-12-23\end{array}$ & $\begin{array}{l}07: 00: 57 \\
05: 00: 57\end{array}$ & $\begin{array}{l}+3.851 \\
43.827\end{array}$ & $\begin{array}{l}54.774 \\
57.846\end{array}$ & $\begin{array}{l}6.1 \\
6.1\end{array}$ & $\begin{array}{l}0 \\
0\end{array}$ & $\begin{array}{l}\text { Yes } \\
\text { Yes }\end{array}$ & $\begin{array}{l}\text { Yes } \\
\text { Yes }\end{array}$ & $\begin{array}{l}\text { Caspian Region } \\
\text { Caspian Regian }\end{array}$ \\
\hline 14 & 7] $-0.3-23$ & $06: 59: 566$ & 61.287 & 56.466 & 5,6 & 0 & Yes & Yes & Northern Urals \\
\hline $\begin{array}{l}15 \\
16 \\
17 \\
18 \\
19\end{array}$ & $\begin{array}{l}71-07-10 \\
71-0 ? 1-19 \\
71-10-04 \\
71-10-22 \\
71-12-22\end{array}$ & $\begin{array}{l}16: 59: 59 \\
11: 00: 07 \\
10: 00: 03 \\
05: 00: 00 \\
06: 59: 56\end{array}$ & $\begin{array}{l}64.168 \\
57.777 \\
61.613 \\
51.575 \\
47.872\end{array}$ & $\begin{array}{r}55.183 \\
41.098 \\
47.116 \\
57.536 \\
+8.222\end{array}$ & $\begin{array}{l}5.3 \\
4.5 \\
5.1 \\
5.3 \\
6.0\end{array}$ & $\begin{array}{c}D \\
N \\
13 \pm 29 \\
6 \pm 18 \\
0\end{array}$ & $\begin{array}{l}\text { Yes } \\
\text { Yes } \\
\text { les } \\
\text { Yes } \\
\text { Yes }\end{array}$ & $\begin{array}{l}\text { Yes } \\
\text { No } \\
\text { No } \\
\text { Yes } \\
\text { Yes }\end{array}$ & $\begin{array}{l}\text { W. Slope of lrals } \\
\text { Irals Region } \\
\text { Western Russia } \\
\text { Southern UralF } \\
\text { North of Caspian }\end{array}$ \\
\hline $\begin{array}{l}20 \\
21 \\
22 \\
2.3 \\
24 \\
25 \\
\because 6 \\
25\end{array}$ & $\begin{array}{l}72-07-09 \\
72-07-14 \\
72-08-20 \\
72-09-04 \\
72-09-21 \\
72-10-03 \\
72-11-24 \\
72-11-24\end{array}$ & $\begin{array}{c}- \\
- \\
0 ?: 50: 58 \\
07: 00: 04 \\
0: 1: 00: 01 \\
0: 5: 59: 58 \\
09: 00: 08 \\
0: 5: 51: 58\end{array}$ & $\begin{array}{l}49.9 \\
55.8 \\
+9.962 \\
67.689 \\
52.127 \\
+6.848 \\
52.779 \\
55.843\end{array}$ & $\begin{array}{l}35.2 \\
47.4 \\
+8.179 \\
33.745 \\
51.994 \\
45.010 \\
51.067 \\
64.152\end{array}$ & $\begin{array}{l}5.0 \\
3.5 \\
5.7 \\
7.6 \\
5.1 \\
5.8 \\
4.7 \\
5.2\end{array}$ & $\begin{array}{c}- \\
- \\
0 \\
7=30 \\
28=19 \\
0 \\
N \\
0\end{array}$ & $\begin{array}{l}\text { Yos } \\
\text { les } \\
\text { Yes } \\
\text { Yes } \\
\text { Yes } \\
\text { Yes } \\
\text { Yes } \\
\text { No }\end{array}$ & $\begin{array}{l}\text { No } \\
\text { No } \\
\text { Yes } \\
\text { No } \\
\text { Yes } \\
\text { Yes } \\
\text { No } \\
\text { Yes }\end{array}$ & $\begin{array}{l}\text { North of Black Sea } \\
\text { North of Caspian } \\
\text { North of Caspian } \\
\text { Western Russia } \\
\text { Southern Lrals } \\
\text { Northwest of Caspian } \\
\text { Western Russis } \\
\text { Southeastern I'rals }\end{array}$ \\
\hline $\begin{array}{l}28 \\
29 \\
30 \\
31 \\
32\end{array}$ & $\begin{array}{l}7.3-00-15 \\
73-08-28 \\
73-09-19 \\
73-09-30 \\
73-10-26\end{array}$ & $\begin{array}{l}01: 59: 58 \\
02: 59: 58 \\
02: 59: 57 \\
04: 51: 57 \\
05: 59: 58\end{array}$ & $\begin{array}{l}+2.711 \\
50.550 \\
45.635 \\
51.608 \\
53.656\end{array}$ & $\begin{array}{l}67.410 \\
68.395 \\
67.850 \\
54.582 \\
55.375\end{array}$ & $\begin{array}{l}5.3 \\
5.3 \\
5.2 \\
5.2 \\
4.8\end{array}$ & $\begin{array}{l}0 \\
0 \\
0 \\
0 \\
0\end{array}$ & $\begin{array}{l}d \\
d \\
d \\
d \\
d\end{array}$ & $\begin{array}{l}\text { Yes } \\
\text { Yes } \\
\text { Yes } \\
\text { Yes } \\
\text { Yes }\end{array}$ & $\begin{array}{l}\text { Northwest of Tashkent } \\
\text { N. Kazakh Desert } \\
\text { C. Kazakh Desem } \\
\text { Southern Urals } \\
\text { Southern Urals }\end{array}$ \\
\hline
\end{tabular}

${ }^{a}$ NEIS = National Earthquake Information Service (fortuerly NOAA and USC\&GS).

$b_{\text {SIPRI }}$ Stockholm Intertational Peace ReBearch Institute.

${ }^{c}$ This event was near the Semipalatinsk testing area but fell well outside the a rea of all previous Soviet evants at the time it occurred. Significant amounts of atmospheric radioactivity were reported in association $w$ ith this event $34,36,37,38,39$ leading to speculation that it was a PNE nuclear crat iring event. 70.41

${ }^{d}$ Date of event is after publication of SIPRI report.

\section{i4 nuclear explosions which have con-}

tribited to their PNE program. Seismic evidence presented in Table 3 and Fig. 33 would indicate some 32 events including 6 in 1971,8 in 1972 , and 5 in 1973 thro"igh November 1, 1973 . It thas appears that the Soviets have carried out at least 19 PNE events in addition to those described in this report and that their PNE program has experienced a great acceleration during the last several years. 


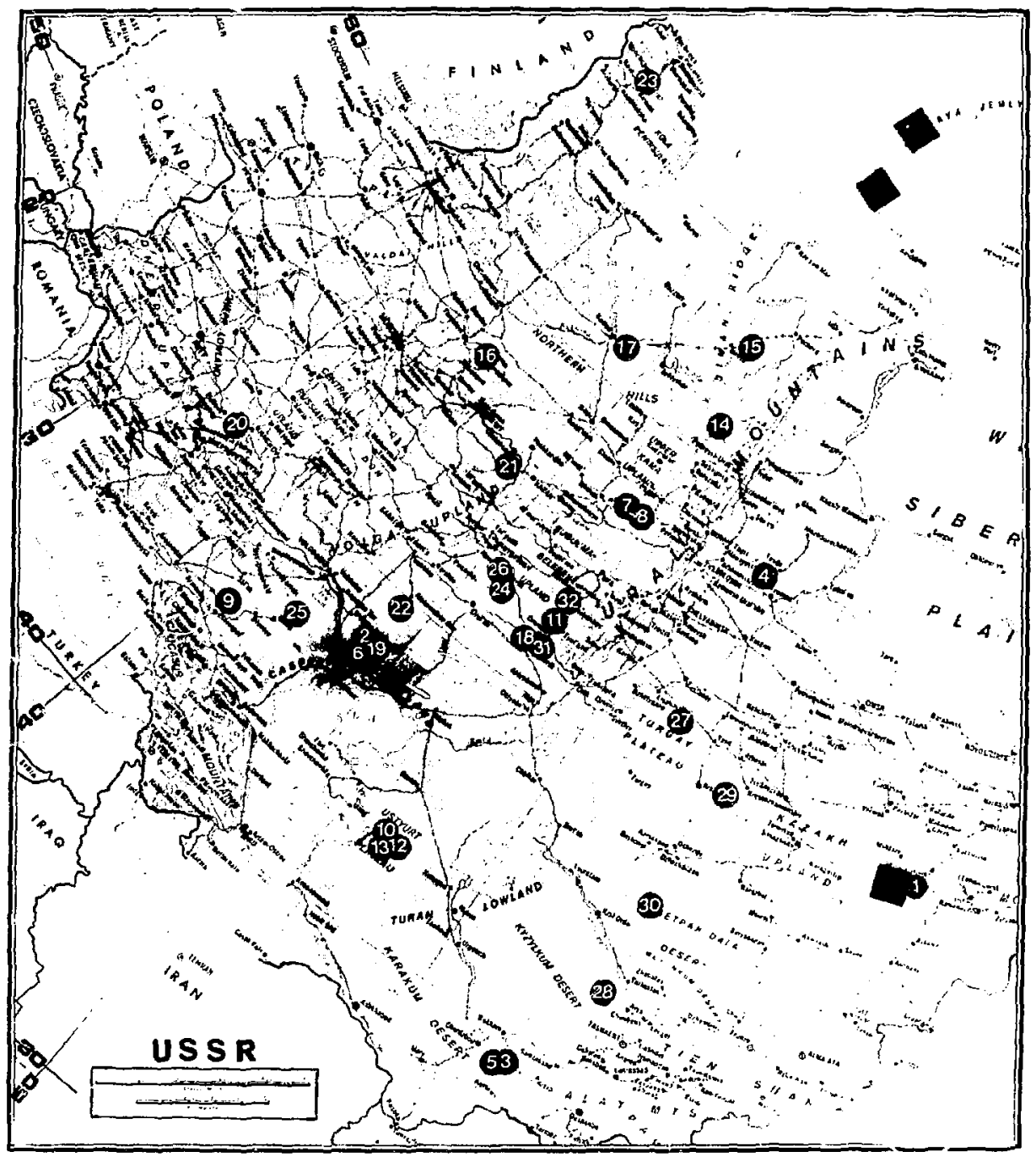

Fig. 33. General locations of presurned nuclear events located away from the normal weapons test sites at Semipalatinsk and Novaya Zemlya (shown by squares). 


\section{References}

1. Review of Possible Peaceful Applicarions of Nuclear Explosions in the National Economy of the Soviet Lnion, Moscow, 1969, V.S. Atomic Energy Commission, Rept. AEC-tr-7121 (1969).

2. O. L. Kedrovskiy, Prospective Applications for Underground Nuclear Explosions In the National Economy of the USSR, presented at the 1st IAEA Panel of Peaceful Uses of Nuclear Explosions, March 1971, Lawrence Livermore Laboratory, Rept. LCRL-Trans-10477 (1970).

3. O. L. Kedrovskiy, "Industrial Uses of Underground Nuclear Explosions," Nuclear Explosions for Peaceful Purposes, I. D. Morokhov, Ed., (Atomizdat, Moscow, 1970), Lawrence Livermore Laboratory, Rept. UCRL-Trans-10517 (1970).

4. O. L. Kedrovskiy, et al. , Collection of Translations of French and Soviet Fapers presented at the 2nd LAEA Panel on the Peaceful Uses of Nuclear Explosions, January I971, Lawrence Livermore Laboratory, Rept. UCRI-Trans-10543 (1971).

5. "Extinguishing a Gas Well Blaze," and "Creating a Water Reservoir," two Soviet movies.

6. O. L. Kedrovskiy, private communication, 1970.

7. Y. A. Izrael, et al., "Radioactive Contamination of the Atmosphere and Ground by Single and Multiple Underground Nuclear Cratering Explosions," Nuclear Explosions for Peaceful Purposes, (see Ref. 3).

8. K. V. Myasnikov, et al., "Mechanical Effects of Single and Multiple Underground Nuclear Cratering Explosions and the Properties of the Excavation Dug by Them," Nuclear Explosions for Peaceful Purposes, (see Ref. 3).

9. J. Toman, Summary of Nuclear Excavation Applications, Lawrence Livermore Laboratory, Rept, LCRL-72220 (1970).

10. "Decision of the USSR State Geological Committee," Razvedka i Okhrona Nedr (Journal of Exploration and Zonservation of Deposits), 1, 16-20 (1965).

11. V. G. Vasil'ev, Gas Deposits of the USSR, (izdated'stov "Nedra," MLascaw, 1968), pp. $626-628$.

12. V. Gubarev, "Taming and Underground Fire," Ukroshchenie nodzemnogo agnya Komsorral'skaya Pravda, 24 September 1970 , Lawrence Livermore Laboratory Rept. UCRL-Trans-10498 (1970).

13. "Torch in the Desert," Fakel b Pustyne, Nauka i Zhizn, 3, 81-82 (1967).

14. S. A. Orudjev, Et al., "Underground Nuclear Explosion to Stimulate Oil Field Development," Proceedings of the 8th World Petroleum Congress, Mosrow, June 1971.

15. B. Rubin, et al. Economic Evduation of Sovitt Secondary Oil Recovery Nuclear Stimulation, Lawrence Livermore Laboratory, Rept. SDK 71-9 (1971). 
16. J. Charlon, Fracturing by Nuclear Explosives to Increase Oil Recovery from Carbonate Reservoirs, presented at the 8th Arab Petroleum Congress, June 1972, Algiers, Geonuclear-Nobel Paso, Paris.

17. G. Higgins, "Summary of Nuclear Explosion Data for Underground Engineering Applications," Proceedings of the 1st IAEA Panel on Peaceful Uses of Nuclear Explosions, March 1970, Lawrence Livermore Laboratory, Rept. UCRL-50853 (1970).

18. J. Faure, Research on Geologic Effects of Underground Nuclear Explosions in a Sahara Granite Massif (Vol. II), thesis presented at University of Nancy, Dec. 1970, Lawrence Livermore Laboratory, Rept. UCRL-Trans-10615, Pt. 2 (1972).

19. G. C. Werth, Ed., The Handcar Nuclear Explosion in Dolomite, Lawrence Livermore Laboratory, Rept, UCRL-50951 (1970).

20. J. H. Howard, Soviet Nuclear Fracturing an Economic Success, Lawrence Livermore Laboraiory, Rept. SDK 72-9 (1972).

21. G. G. Babalyan and M. G. Ovanesov, "Intensification of the Development of Massif-Type Oil Pools in Carbonate Rocks," Geologiya Nefti i Gaza, 11 , 16-19 (1970).

22. C. R. Stewart, et al., "The Role of Bubble Formation in Oil Recovery by Solution Gas Drives in Limestones, "Stanoilind Oil and Gas Co., AIME Petroleum Transcription 3962, J. Pet. Tech., (1954).

23. K. V. Myasnikov, et al., Razrabotka Nauchno-Technisheskeskikh Osnov Sozdaniya Podzemnykh Khranilishch 5 Pomoshch'ya Yadernykh Vzryvov v Massive Kamennoi Soli, presented at 3 rd LAEA Panel on Peaceful Uses of Nuclear Explosives, LAEA PL-388-3/19, Vienna, Austria, November 1972. (See also Lawrence Livermore Laboratory, Rept. UCRL-Trans-10701.)

24. P. A. Witherspoon and D. L. DePasguale, Economics of Underground Gas Storage in Craters Created by Nuclear Explosives, Lawrence Livermore Laboratory, Rept. UCRL-13354 \{1968).

25. P. L. Randolph, "Gas Storage Applications of PNE," El Paso Natural Gas Co., presented at 2nd IAEA Panel on Peaceful Uses of Nuclear Explosives, Vienna, Austria, IAEA PL-429/7, January 1971.

26. T. J. Lassiter and $P$. A. Witherspoon, Preliminary Results on the Feasibility of Storing LNG in Underground Cavities Created by Nuclear Explosives, Trans. Am. Nuclear Soc. 1971 Winter Meeting, Miami, FL, October 17-21, 1971.

27. K. Parker, The Storage of Natural Gas in Cavities Created by Underground Nuclear Explosions, AWRE, presented at 2nd IAEA Panel on Peaceful Uses of Nuclear Explosives, IAEA-PL-429/16, Vienna, Austria, January 1971.

28. A. Borthoux, et al., Etude de Cavites de Stockage por Moyens Nucleaires, CEA, presented at 3rd IAEA Panel on Peaceful Uses of Nuclear Explosives, IAEA PL-388-3/1, Vienna, Austria, November 1972.

29. D. E. Rawson, et al., Review of the Salnion Experiment, A Nuclear Explosion in Salt. Die Naturwissenschaften, 20, p. 525-531(1967). 
30. I. Y. Borg, Shock Effects in Granodiorite to $270 \mathrm{kbar}$ at the Plledriver Site, Lawrence Livermore Laboratory, Rept. UCRL-73377 (1971). (to be published in J. Geoph. Res.)

31. S. Derlich, "Transformation du Milieu dues a' une Explosion Nucleaire Souterraine," CEA, Proceedings of the 1st LAEA Panel on Peaceful Uses of Nuclear Explosions, international Atomic Energy Commission, Vienna, LAEA-PL-338/10, (1970) p. $123-138$.

32. World Armaments and Disarmament - SIPRI Yearbook 1972 (Stockholm International Peace Research Institute, 1972).

33. The Implementation of International Disarmament Agreements (Stockholm International Peace Research Institute, 1973).

34. U.S. Announced Recordings of Seismic Signals Presumably from Soviet Underground Nuclear Tests, USAEC, Office of Information Services.

35. Earthquake Data Reports, U.S. Dept. of Interior, U.S. Geological Survey, Boulder, Colorado,

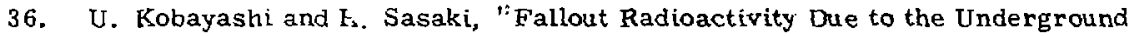
Nuclear Test of USSR - Jan. 15, 1965," Journal of Radiation Research: (2), 64-72 (1965).

37. N. Mu rayama, "Radiation Fallout from the Thrəe Nuclear Explosions for Late 1964 and Early 1966," Koshacho Kenkya 17, 246-58 (1968).

38. T. Mamuro, et al., "Observations of Fallout Around Our Laboratory," Report of the Radiation Center of Osaka Prefecture 6, 1-4 (1965).

39. S. Koyama, et al., "Highly Fractionated Nuclear Debris Resulting from the Venting of a Soviet Underground Nuclear Test," Nature 209, (5020), 235-240 (1962).

40. P. D. Marshall, ei al., "Surface Waves from Underground Explosions," Nature 234, 8.9 (1971).

41. K. Parker, "Engineering with Nuclear Explosives - Achievements and Prospects," . Inst. Nur. Eng. 12, (60), 155-162 (1971). 


\section{Appendix A \\ Urtabulak Field *}

The Urtabulak gas-condensate field lies $90 \mathrm{~km}$ south of Karaulbazar. Exploration-prospecting drilling was started in 1961, and industrial gas reserves in the Jurassic carionate deposits were found in 1963.

The geologic structure of the field invo ves a complex of Meso-Cenozoic deposits. The Lower and Middle Iurassic deposits, opened to a depth of over 400 meters, are represented by terrigenous sediments (argillites, siltstones, and sandstones). The Upper Jurassic, 1030 meters thick, consists here of limestones and in the upper part of a fairly thick (365-675 meters) salt-anhydrite series of the Gaurdakskaya suite. The Cretaceous and Tertiary deposits are represented fredominantly by terrigenous marine sediments. The overall thickness of the Meso-Cenozoic deposits opened up oy drilling is 3430 meters; no Paleozoic rocks have been reached.

The Urtabulak fold forms part of the southea'tern sector of the Dengizklil'skaya group : structures which complicates the southwestern margin of the Karakul'skii trough of the Chardzhouskaya stage of the Paleozoic basement. Along the roof of the Bukhara limestones the fold represents a brachyanticline of latitudinal strike. The arch part of the structure is complicated by graben oriented parallel to the fold axis. The graben in turn is disturbed by a fault of southeustern strike.

\footnotetext{
${ }^{*}$ From Ref. 11, pp. 626-8.
}

The structural plane changes sharply with depth. Thus, the arch of the fold along the Jurassic subsalt deposits relative to the position with respect to Paleogene rocks is shifted by almost $3 \mathrm{~km}$ toward the southwest. The fold relief becomes more pronounced; the height is not less than 210 meters. The strike of the fold changes to a northeastern one (see Fig. 18).

The gas deposit, confined to the fissured carbonate rocks of horizon XV of the subsalt Jurassic, was found by Well 11 that had been in a runaway condition for over two years without any noticeable decrease in the gas flow. According to various calculations the output of this well is $8-12$ million $\mathrm{m}^{3}$ of gas per day and the formation pressure is $27-300 \mathrm{~kg} /$ $\mathrm{cm}^{2}$. Well 11 penetrated only the upper part of the productive horizon, with a depth of 2409 meters.

Apart from this, the gas reserves of the roof part of the subsalt deposits were established in the tesiing of Well 16. Hare the productive deposits are represented by limestones with intercalations of anhydrites. In the interval between 2465 and 2475 meters, the gas flow at the $24.7 \mathrm{~mm}$ connector pipe was $216,800 \mathrm{~m}^{3} /$ day, with an absolutely free flow of $980,000 \mathrm{~m}^{3} /$ day. According to the work with Well 16, the formation pressure in the depos it is $254 \mathrm{~kg} / \mathrm{cm}^{2}$.

The open-pore porosity of the collectors of the productive horizon is-according to industrial geophysical data-not more than $9 \%$, while the permeability amounts 
to 140 mdarc $\%$. The presumed height of the dejosit of horizon XV is 160 meters. The deposit measures approximately $18 \times 7 \mathrm{~km}$.

The gas has a density of 0.64 and cuntains up to $88.2 \%$ of methane. A characteristic feature of this gas deposit is the very high content of hydrogen sulfide in the gas, reaching-according to
SredazNIIG data $-7.9 \mathrm{wt} \%$ or $6 \mathrm{~kg}$ of sulfur per $1000 \mathrm{~m}^{3}$ of the gas. The forma. tion gas contains condensate, whose amount has not been determined.

The field is still being explored. In January 1,1968 , its reserves were estimated at 23 billion $\mathrm{m}^{3}$ according to categories $\mathrm{A}+\mathrm{B}+\mathrm{C}_{1}$, including 6.2 billion $\mathrm{m}^{3}$ for categn-ies $A+B$. 